\title{
How to Encourage Energy Savings Behaviours? The Most Effective Incentives from the Perspective of European Consumers
}

\author{
Sylwia Słupik $1, * \mathbb{( D}$, Joanna Kos-Labędowicz ${ }^{2}$ (1) and Joanna Trzęsiok ${ }^{3}[$ \\ 1 Department of Social and Economic Policy, University of Economics in Katowice, 1 Maja 50, \\ 40-287 Katowice, Poland \\ 2 Department of International Economic Relations, University of Economics in Katowice, 1 Maja 50, \\ 40-287 Katowice, Poland; joanna.kos@ue.katowice.pl \\ 3 Department of Economic and Financial Analysis, University of Economics in Katowice, 1 Maja 50, \\ 40-287 Katowice, Poland; joanna.trzesiok@ue.katowice.pl \\ * Correspondence: sylwia.slupik@ue.katowice.pl
}

Citation: Słupik, S.; Kos-Łabędowicz, J.; Trzęsiok, J. How to Encourage Energy Savings Behaviours? The Most Effective Incentives from the Perspective of European Consumers. Energies 2021, 14, 8009.

https://doi.org/10.3390/en14238009

Academic Editor:

Dimitrios Katsaprakakis

Received: 25 October 2021

Accepted: 23 November 2021

Published: 30 November 2021

Publisher's Note: MDPI stays neutral with regard to jurisdictional claims in published maps and institutional affiliations.

Copyright: (c) 2021 by the authors. Licensee MDPI, Basel, Switzerland. This article is an open access article distributed under the terms and conditions of the Creative Commons Attribution (CC BY) license (https:/ / creativecommons.org/licenses/by/ $4.0 /)$.

\begin{abstract}
Ongoing climate change and increasing energy consumption are becoming a serious threat to international development efforts. To ensure a secure and sustainable future, local, national and regional authorities, as well as energy companies, need to be involved in improving energy efficiency and promoting rational energy use. The consumer is always at the centre of interest of policy and energy reduction strategies makers. It is their behaviour, motives and beliefs that can lead to optimised and economical energy management. This paper responds to the need to identify the individual preferences of energy consumers. The presented research fills an existing gap in the literature by analysing the strength of the influence of different types of instruments and external stimuli shaping pro-environmental attitudes of consumers of different behavioural types. The analysis presented in this paper is the result of the next stage of the authors' research on energy consumers modelling, their segmentation and comprehensive characteristics. The analysis was conducted on a representative sample of $\mathrm{N}=4332$ respondents from 8 European countries (Czech Republic, France, Greece, Spain, Germany, Poland, Romania, and the United Kingdom). The study used multivariate statistical methods, such as: Correspondence Analysis, Factor Analysis and Kruskal-Wallis test. These methods are adequate to the assumptions of the research procedure and allowed for the identification of 4 latent factors that link the incentives into groups, where the motivation to save energy is based on: information ("Information and Knowledge"), social norms ("Social Influence"), investment funding ("Investments") and energy price changes ("Energy Price"). In addition, the level of effectiveness of the studied incentives and motivators depends on the behavioural type of energy consumers and increases with rising levels of their intrinsic pro-environmental motivation.
\end{abstract}

Keywords: behavioural energy consumer segmentation; European consumers; energy consumption; energy efficiency; home energy management; energy saving incentives; multivariate statistical analysis

\section{Introduction}

As one of the pillars of energy security for the whole European Union, energy efficiency plays an extremely important role in EU policy. The "Fit for 55" package [1,2], announced in July 2021, set the fight against climate change as one of the main tasks for the European Community policies and as a challenge for society, states, international organisations as well as energy companies. The latter, faced with the ambitious assumptions of the economic transformation plan towards climate neutrality by 2050, consider account of these changes in their strategic planning. The increase in demand for electricity and the rising prices of energy raw materials may make it necessary to ensure an adequate supply of low-carbon 
energy and to plan the expansion of the energy system in detail, also in order to prevent the risk of instability in the transmission and distribution networks. Therefore, the longterm strategic management of energy companies in the area of individual energy demand should focus on dialogue with consumers, as their primary stakeholders most affected by the changes taking place. On the other hand, consumers are also the initiators of these changes. The growing ecological awareness, expectations regarding the introduction of energy-efficient solutions, clean technologies, and concern for the environment translate into changing trends and patterns of consumption, including energy consumption. These attitudes and expressed beliefs are forcing changes in traditional thinking and management approaches, as well as creating new challenges for energy companies. Adapting to the changing needs of consumers requires ambitious measures, not only in terms of optimising technological processes but also in relation to meeting Member States' energy-saving commitments. Therefore, energy companies should encourage appropriate customers' attitudes towards energy efficiency and energy saving behaviours. Energy companies should take into account issues related to sustainable development both in their ongoing decisions and while creating long-term strategies. An in-depth understanding of consumers' needs, preferences, and individual expectations/requirements is crucial in order to optimise management and adapt the offer for different social groups/consumer types.

This paper responds to the growing requirement to identify individual energy consumer preferences, their motivations both internal and external, the effectiveness of different types of incentives in creating energy behaviours and managing energy demand. The obtained results and carried out analysis can be useful not only for energy companies but also policy makers and national and regional authorities to develop effective strategies and projects dedicated to educating and informing consumers in order to encourage proecological and energy-saving behaviours. Therefore, the objectives of this article can be formulated as follows:

1. Re-evaluating the assumptions of the authors' behavioural segmentation of energy consumers [3]. The results obtained in this stage will once again verify the correctness of the developed concept for the division of energy consumers in terms of the dominant intrinsic motivation to save energy;

2. Supplementing the characterisation of the different behavioural types by the types of external incentives and examining the strength of their influence on the obtained segments. The authors' intention was to examine the strength of influence in terms of its effectiveness to induce consumers to carry out energy-saving activities;

3. Due to a large number of examined incentives, attempt to combine individual incentives into relevant latent factors and to check, at a further stage, how individual behavioural types of consumers react to these obtained factors. Reducing the number of incentives will allow for a more effective adaptation of the types of instruments to the analysed segments of energy users.

It should be emphasised that the analysis presented in this article is the result of the next stage of the authors' research into the behaviour patterns and types of energy consumers $[3,4]$. The research has been conducted on a representative research sample of $\mathrm{N}=4506$ respondents from 8 European countries. The characteristics of the research sample and the adopted assumptions are described in detail in the Materials and Methods section.

The analysis presented in this paper aims to extend existing knowledge on the strength of the influence of external incentives and factors motivating particular behavioural types of consumers to take energy-saving actions. Moreover, the authors hope that the presented results will fill the observed research gap in this field. There are few studies that attempt to combine the application of a particular type of intervention with a specific behavioural or socio-demographic profile of the consumer. It is also very rare for researchers to examine the effectiveness of particular incentives, especially taking into account the consumer's dominant motivation for taking action. Authors who have conducted such studies have usually reported a number of barriers in the methodological approach. They either had a 
small sample that could not be statistically verified, or they did not obtain the necessary data to conduct the analysis.

Full characterisation of the different types of energy consumers complemented by the types of incentive and their impact in reaching particular individuals, resulting from the analysis conducted using multivariate statistical methods is the original contribution of this paper. The obtained results may be helpful in developing programmes and campaigns, e.g., to encourage energy savings and the implementation of instruments to protect against negative climate impacts as well as EU energy efficiency and climate policies. In addition, the obtained insight into consumers' motivations and behaviours may be used by energy companies as a knowledge base and basis for the development of effective demand management plans and the design of customised intervention tools.

The paper is divided into 6 main sections, starting with an Introduction (1) providing the background and justification for undertaking the research. This section also includes the primary objectives of the study and an indication of the authors' innovative contribution. Section 2 focuses on a literature review, to which the authors also refer in Section 5 for a discussion of the results. Section 3 presents the methodology used in the study. Section 4 contains the obtained results along with their interpretation and Section 6 ends the paper with the most important conclusions.

\section{Literature Review}

For a long time now, energy efficiency measures (EEM) have played a huge role in the implementation of the European Union's climate and energy policy. The progressing decarbonisation of the Member States' economies is becoming an opportunity to increase competitiveness, create new jobs and improve air quality [5]. The approach to this subject is multi-faceted, ranging from the question of objectives, financing, the creation of adequate and good legislation to the implementation of energy efficiency in various sectors. Therefore, the role of individual incentives for energy efficiency implementation as well as instruments shaping energy demand management cannot be overestimated.

Meeting the goals associated with improving/reaching energy efficiency can be achieved through numerous ways, starting with increasing the efficiency and effectiveness of the energy system itself (both infrastructure and different devices used by individual and commercial users), streamlining the flow and management of important data, promoting and implementing good power-related practices and other.

The effectiveness of available equipment in terms of power consumption has improved significantly over the recent years [6] and one can expect this trend to continue, due to the potential in this regard. The growing interest, awareness and acceptance of innovative solutions among potential users $[7,8]$, combined with regulations implemented both at EU, national and regional (or urban) levels [5] put additional pressure on the manufacturers and vendors of energy and equipment.

At the same time, it should be noted that environmental issues meet with increasing social understanding and the problems of natural environment quality are becoming an increasingly important component in the awareness of an average consumer. Regardless of the motivations and individual beliefs, even when individuals do not exhibit the readiness to bear additional costs associated with caring for the environment, consumers see the need for change. This is why the understanding of the motives, attitudes and conditions driving the everyday consumer behaviours and further strengthening of the approval for sustainable development are the keys to developing pro-ecological mindsets.

However, it should be noted that most of the existing research on energy consumption behaviour is limited in scope or focus only on a particular aspect [9]. It does not take into account, for example, demographic or social factors that contribute to household energy consumption and the design of infrastructure that determines behavioural choices and energy use [9]. The significant impact on energy consumption of a number of complex interlinked socio-economic and demographic factors is confirmed by [10] studies. 
Research [11,12] indicates that consumer behaviours underpin many complex environmental problems and that interventions targeting consumer behaviours offer a cost-effective approach to energy conservation [13-15].

In the literature, there are many classifications of existing incentives, instruments and stimuli aimed at shaping pro-environmental behaviour of energy consumers and at managing energy demand [16-25]. Gillingham et.al [26], reviewing the literature on types of energy efficiency policies, distinguished the following types of instruments that can influence pro-saving behaviours and help to estimate their costs: appliance standards; financial incentive programs; information and voluntary programs; management of government energy use. Additionally, Cattaneo [19] points to three basic types of incentives: informational instruments, regulatory instruments; economic and financial instruments. Furthermore, her study combines individual incentives with barriers to energy efficiency, related to both energy consumption and investment in energy efficiency technologies. Whereas Annika Carlsson-Kanyamaa and Anna-Lisa Linden [27,28] distinguish physical instruments in addition to information, economic and administrative instruments. The type of incentives involves the introduction of physical improvements e.g., displays monitoring the energy consumption of various household appliances. The investments in tools to manage energy and immediately inform the user about the amount and effects of consumption also count as potential tools from this group. The authors indicate that such instruments, in order to be effective in shaping a new/ecological behaviour pattern, should be additionally combined with other types of measures, e.g., economic or educational ones. Similar to [19] del Mar Solà et.al [29] reviewed the policy instruments used to promote energy efficiency and discussed their effectiveness. Furthermore, her study identified the main limitations of energy efficiency policies, pointing out for example the differences in the effectiveness of rebate schemes, the inconclusive results of the effectiveness of monetary energy efficiency labels or the difficulties in implementing standards.

Some of the studies conducted analyses of the effectiveness of specific energy efficiency incentives and policies based on evidence from literature [29-35]. The most common division of incentives and instruments distinguishes two basic groups: financial incentives (grant and loan facilities, subsidies, tax deduction, tax credits, rebates, guarantees, and energy taxes) and non-financial incentives (information, product labelling, feedback, audits, educational instruments, gamification, social influence, regulatory instruments, and various types of policies).

Filippini et al. [36] carried out an econometric estimation of energy efficiency levels in the residential sector in the EU27 countries and showed that financial incentives, together with the introduction of efficiency standards, played an important role in promoting energy efficiency and reducing energy consumption. Allcot and Tubinsky [37], on the other hand, are sceptical about the use of standards, pointing out that, this type of instrument may reduce the number of choices and generate welfare losses by leading to a change in the behaviour of those consumers who gain little from energy efficiency improvements. Researchers [38-40] argue that people's internal beliefs will be more effective incentives than financial motivation. They point out that short-term economic motivation may result in a lack of savings in the long term when such behaviour is no longer profitable. They also argue that financial incentives are linked to initial investment costs. They do not reward behavioural changes and are not linked to energy consumption. The most common financial incentives used to reduce energy consumption and GHG emissions are taxes, subsidies, combinations of taxes and subsidies, and rebate schemes [29]. Some researchers $[19,29]$ point to the lack of effectiveness of financial incentives, both in terms of improving building efficiency [41] and subsidies for energy-efficient purchases such as more ecological cars [42]. In contrast, others [43] propose an optimal combination of taxes and subsidies. Gholami et al., [44] and Corbett [45] argue that electricity pricing incentives can motivate behavioural change, towards increased energy efficiency. Very often the occurrence of increased consumption [46], the free-riding phenomenon [47], the rebound effect $[38,48,49]$ and the lack of cost-effectiveness of these solutions are given as 
reasons for the ineffectiveness of financial instruments [19,50]. As Cattaneo [19] points out, one of the limitations of economic and regulatory instruments is that they mainly affect investment behaviours.

Interventions aimed at increasing household energy efficiency can apply to numerous aspects and factors impacting energy consumption and energy behaviours. These can include activities associated with, among others, household energy renovations and retrofits [51-53], investing in renewable energy sources (RES) [54,55], energy certificates [56] and labels [57-59], energy audits [60] and consulting [61], advanced energy metering infrastructure/smart meters [62-64], different-purpose subsidies [65] or other financial incentives [66].

Some existing research [38] points to the large role of information, rewards but also technology and the influence of social norms in changing energy behaviours, especially in the short term. Even if sociodemographic characteristics are important when evaluating the potential success of interventions, Spandagos et.al. [67] in their study argue that factors such as openness to change, environmental knowledge and influence history may have a more profound effect. Researchers also attempt to determine the significance of other factors relative to energy-saving behaviours and improving pro-ecological attitudes, such as, e.g., access to culture and participation in cultural activities [68], altruism [69] or communal narcissism [70]. Additionally, an increasing number of studies emphasize the importance of social factors, such as social and political trust in shaping energy-saving behaviours [71].

Although, on the other hand, research [46] indicates that some social information programmes are not as effective as individual information, or the social impact may manifest itself in a boomerang effect [72], when consumers compare their consumption with the higher consumption of their peers.

The obtained results of the research and the full characterization of the profiled energy consumer will be used to better design information tools for informing, educating, and assisting consumers in effective energy management at home. The authors of this paper participated in an international innovative project: "Personalised ICT-tools for the Active Engagement of Consumers Towards Sustainable Energy. Eco-bot", co-funded under Horizon 2020, aimed at creating a user-friendly chat-bot to help optimise energy in residential and commercial buildings [73].

The eco-bot project is designed to fulfil the informative (providing information on energy consumption) and advisory/educational (delivering personalised recommendations on actions that can be taken to use energy more efficiently) roles. Pro-environmental and financial factors can serve as motivators for people to engage in energy-saving behaviours [74]. Experiments using individualised information strategies confirmed that out of four interventions with different themes, environmental input and cost-benefit feedback had the greatest impact on increasing household electricity savings [75]. In contrast to those findings, other research pointed that reducing costs is more important than environmental concerns when deciding about the implementation of eco-innovation [76] or that financial incentives can be the most important factors affecting young people energy behaviours [77]. The link is not so obvious when assessing wider activities associated with the correlation between pro-environmental and pro-energy-saving interventions research by Steinhorst and Matthies [78] demonstrated the limited usefulness of both proenvironmental framing and pro-monetary framing, and their dependence on pro-ecological attitudes of individual recipients.

The presented review of the reference work on energy efficiency and encouraging households to undertake EEMs indicates a high degree of complexity and the multidisciplinary character of the issue in question. It goes without saying that comprehensive and multi-faceted activities, such as combining several different EEMs (e.g., combining energy feedback with financial incentive) [79-81], as well as motivating and engaging users $[82,83]$ are required. It can be noted that self-determined energy-saving actions (taking into account such factors as a person's socio-economic status, type of housing, 
existing knowledge, motivation and ability to engage in energy conservation programs) are more likely to be sustained in the long term and may benefit from support by ICT solutions $[84,85]$ or ICT-based interventions [86].

Taking into account the multitude of instruments and motivators, the authors decided to select for the purpose of this study only those that were most often indicated in the literature as effective.

\section{Materials and Methods}

The analysis, which is the core of this article, was made possible by the data obtained from an online survey that was carried out between March and June 2021, by two research agencies: DRB Polonia and SW Research. The Computer-Assisted Web Interview (CAWI) method, with a novel structured survey questionnaire prepared by authors, was used for the study. The research sample consisted of 4506 respondents from 8 European countries: Czech Republic, France, Germany, Greece, Great Britain, Poland, Romania, and Spain. The sample was selected by the quota method and reflected the population structure of the indicated countries according to gender, age, and place of residence (urban, rural). The selection of countries, in turn, was intended to take into account geographical location as well as cultural, social and income differences or even the climate characteristics. Great emphasis was also placed on indicating those countries, which are characterized by a different energy mix. The authors received a raw, aggregated and anonymised database for further analysis, and research agencies have the remaining data (completed questionnaires) with the obligation to archive them for a period of one year. The authors were primarily interested in exploring the behaviours of energy users, so the questions aimed to identify the basic motivations, opinions, performed activities, and future intentions of the respondents in the area of energy saving. The undertaken study was possible thanks to funding from the eco-bot project.

The first part of the study, presented in the article [3], aimed to divide energy consumers into 5 distinct behavioural types: Ecological Idealist (EI), Aspiring Ecologist (AE), Dedicated Saver (DS), Opportunist (O) and Indifferent (I) using original segmentation model, also described in detail in the authors' previous paper [3]. This segmentation was based on the assumption that people's approach to the problem of energy savings differs mainly in terms of intrinsic motivation and environmental awareness. It is therefore assumed that:

- the Ecological Idealist is an energy user with a very high level of pro-environmental knowledge and awareness of climate issues. High sensitivity to ecology usually drives the behaviours of this type of consumer;

- the Aspiring Ecologist is a consumer who is also characterised by pro-environmental actions and motivations, although is largely influenced by fashion, trends or the behaviours of social groups that are important to them;

- the Dedicated Saver is a person of average sensitivity to climate and ecological problems, who is primarily motivated to save energy by financial considerations;

- the Opportunist is a consumer with even lower environmental awareness, whose pro-environmental behaviours and actions are incidental and performed only when they are easy to implement;

- the last distinct type of user, the Indifferent segment, is generally ignoring ecological problems and not interested in reducing their own energy consumption.

The applied segmentation procedure, allowed for unambiguous assignment of 4332 people to these 5 segments: EI-28.9\%; AE-15.3\% DS - $43.5 \%$; O-4.2\%; I- $4.1 \%$. The remaining respondents, due to their answers to the segmentation questions were simultaneously assigned to at least two groups. However, it should be emphasised that there were only 174 such people $(3.8 \%)$, which is a very good result, confirming the validity of the assumptions adopted in the segmentation. Another part of the research, presented in the article [4], allowed for characterising the 5 identified groups of energy users by socio-economic characteristics. 
This paper presents the results of further research aimed at deepening the created a priori segmentation and supplementing the energy consumer profile with their attitudes towards different types of incentives and instruments potentially stimulating pro-ecological actions. The overriding concept is to create a comprehensive characterisation of the five identified energy user segments, and this paper is a further step towards obtaining a complete picture of the behavioural types of the energy consumers. At the same time, the results presented in this work allow the aforementioned characterisation of segments to be oriented in a way that it may serve as a guideline for policy makers and programmes to combat climate change, counteract high emissions, or promote pro-ecological energy consumption.

The dataset used in the analysis included responses, obtained from 4332 people, to questions exploring their attitudes towards various forms and activities that represent:

- potential incentives to change behaviours to those that are characterized by greater ecological awareness;

- external motivators, stimuli inclining to reduce energy consumption.

All incentives considered in the study are presented in Table 1.

Table 1. External incentives and motivators, included in the survey, which could potentially encourage respondents to save energy.

\begin{tabular}{|c|c|}
\hline \multicolumn{2}{|r|}{ Potential Incentives to Save Energy Include: } \\
\hline 1 & Training or another form of organized education \\
\hline 2 & $\begin{array}{l}\text { Regular updates on energy consumption provided by an energy supplier } \\
\text { (website, phone, direct contact, etc.) }\end{array}$ \\
\hline 3 & Professional audit/analysis of household's energy consumption \\
\hline 4 & Use of a dedicated application or other IT tool (e.g., a chatbot) \\
\hline 5 & Initiatives within local communities aimed at energy saving \\
\hline 6 & $\begin{array}{c}\text { Promotional and informational material from energy companies (leaflets, } \\
\text { brochures, websites) }\end{array}$ \\
\hline 7 & Social campaigns on energy (advertising spots, billboards) \\
\hline 8 & Information obtained from the Internet and social media \\
\hline \multicolumn{2}{|r|}{ Potential Motivators for Behavioural Change Include: } \\
\hline 9 & $\begin{array}{c}\text { Obtaining repayable funding for investments related to energy saving } \\
\text { or (RES) }\end{array}$ \\
\hline 10 & $\begin{array}{c}\text { Obtaining non-repayable funding for investments related to energy saving } \\
\text { or RES }\end{array}$ \\
\hline 11 & Energy self-sufficiency as a result of being an energy producer \\
\hline 12 & $\begin{array}{l}\text { Social influence creating the need for pro-environmental behaviours } \\
\text { incorporated as an internal need for environmental protection }\end{array}$ \\
\hline 13 & $\begin{array}{c}\text { Care about own and family's health translating into care for the quality of } \\
\text { the environment }\end{array}$ \\
\hline 14 & Keeping up with the green trend \\
\hline 15 & Increased energy prices \\
\hline
\end{tabular}

Only the responses of respondents unambiguously assigned to segments were taken into account in the study. The aim was to deepen the characterisation of the segments with further information that could help in a more personalised approach to energy consumers and the responses of ambiguously classified respondents could distort the obtained results.

In each case considered, the respondent indicated to what extent they considered the incentive to be helpful or effective in getting them to save energy. The possible answers, on a five-point Likert scale, have been supplemented by adding the intensity, expressed as a percentage, which referred to the degree of effectiveness or helpfulness (e.g., definitely effective $(100 \%)$, quite effective $(75 \%)$, neither effective, not ineffective $(50 \%)$, quite ineffective $(25 \%)$, completely ineffective $(0 \%))$. The choice options presented in this way allow to treat the obtained answers, on the one hand, as variables measured on an ordinal scale and, on the other hand, as quantitative variables. This in turn translates into an expanded group of statistical methods that can potentially be used to analyse these data. 
The purpose of the analysis conducted for this paper was to answer the following research questions, related to the objectives outlined in the Introduction:

1. Which of the stated incentives are significantly associated with the behavioural types of energy consumers?

2. Is it possible to group the studied incentives and thus identify latent factors that are combinations of those observable, indicated and evaluated by respondents?

3. Do the created factors-hidden incentives, differ in terms of the strength of influence in groups of respondents classified into different segments?

In this way, the analysis can be also divided into 3 main stages:

Step 1. The Chi-square test [87,88] and Correspondence Analysis [89-91] were used to identify the relationship between the studied motivators (incentives) and the type of consumer. This additionally performed analysis made it possible to associate individual segments of energy users with their most frequently declared degree of inclination toward using particular incentives.

Step 2. Due to the relatively large number of studied incentives, it was checked whether it is possible to group them and thus create a smaller set of variables. This is tantamount to creating new latent factors. Principal Component Analysis (PCA) is a method dedicated to such a study [92-95]. For the purpose of this study, Cronbach's alpha coefficient [96] was also used to check the reliability of the scale. That way the results obtained by Principal Components Analysis were confirmed.

Step 3. In a final step, the Kruskal-Wallis test $[97,98]$ was used to test whether respondents who were assigned to different behavioural types differed significantly in their susceptibility, propensity to particular incentives. This test was used because the assumptions of the classical ANOVA were not met.

It is worth emphasising that answering the research questions was possible thanks to applying appropriate methods of data analysis. Application of the above-mentioned methods, resulted among others from the scale of measurement of variables, which in many cases determines the choice of appropriate statistical tools. In addition, methods that corresponded to the objectives of the study were used. The identification of relationships between nominal variables and their categories was possible thanks to the Chi-square test and Correspondence Analysis, which are tools dedicated to this type of analysis. In turn, the reduction of the number of variables and the identification of latent factors are in line with the assumptions of Principal Component Analysis. The Kruskal-Wallis test, which is a non-parametric equivalent of the Analysis of Variance, is also a suitable tool for testing the significance of differences between the values of variables observed in different groups.

Due to the applicative character of the paper, as well as the widespread access to relevant literature on the subject, detailed descriptions of the methods used have been omitted, as they are not necessary to explain the achieved results.

\section{Results}

The analysis was performed in three steps, which corresponded to the posed research questions. Therefore, the results are also presented in three following sub-sections.

\subsection{Analysis of the Impact of Different Incentives on Behavioural Types of Energy Users}

The analysis began by performing a Chi-square test to see which of the incentives and motivators declared by the respondents are dependent on the behavioural types of these energy consumers. In practice, this meant that 15 tests were performed. Two variables were taken into account in each test: (1) the respondent's assignment to a segment (treated as a nominal variable with five categories), (2) each of the incentives listed in Table 1. The results obtained show that for each tested pair "behavioural type-the incentive" a significant relationship was detected, as for all calculated Chi-square test values, the corresponding $p$-value was less than 0.001 . 
Identifying the indicated relationships allowed to extend the research by performing Correspondence Analysis. In this way, it was possible to show how the individual segments to which the respondents were assigned are related to their declared degree of usefulness/helpfulness of individual instruments motivating them to save energy. Correspondence Analysis is an exploratory research technique dedicated to non-metric variables, which has the advantage of allowing for creation of a so-called Correspondence map. It allows for an easy interpretation of the results obtained: the closer the points, representing segments and the strength of the impact of incentives and motivators, lie to each other, the more strongly they are related. Figure 1 presents six examples of Correspondence maps. The selected maps represent three differentiated examples each, from the group of incentives and motivators shown in Table 1. Correspondence maps of other instruments promoting energy efficiency can be found in Figure A1 in Appendix A.

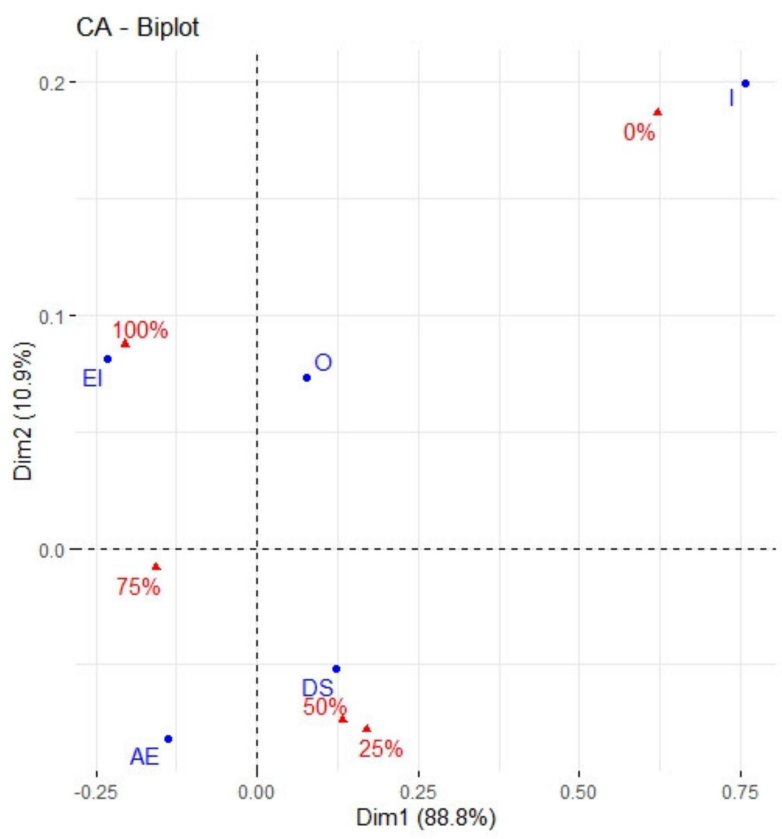

(a)

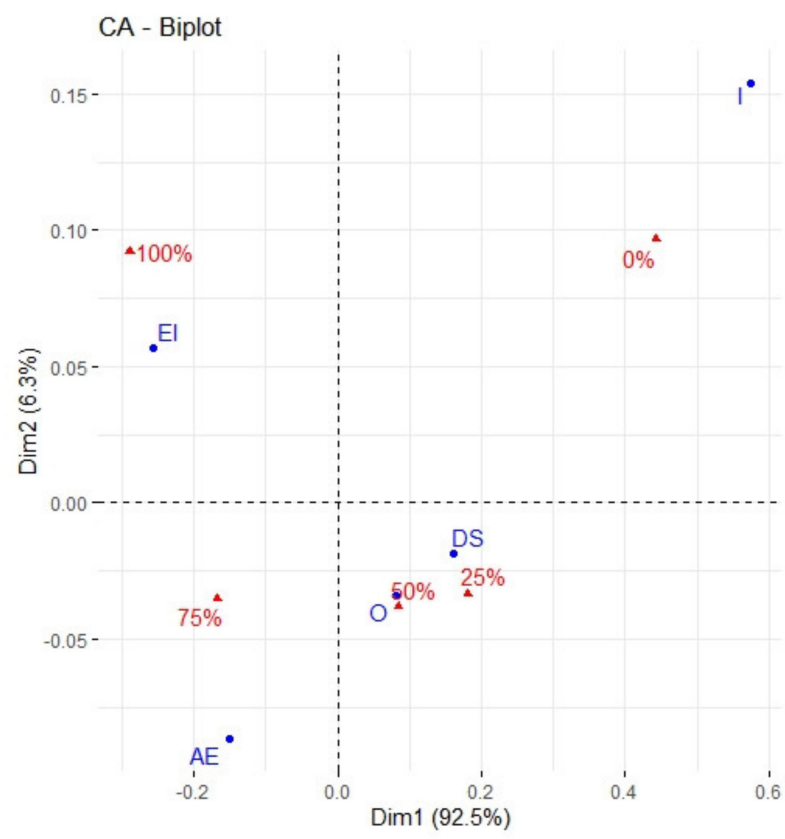

(b)

Figure 1. Cont. 


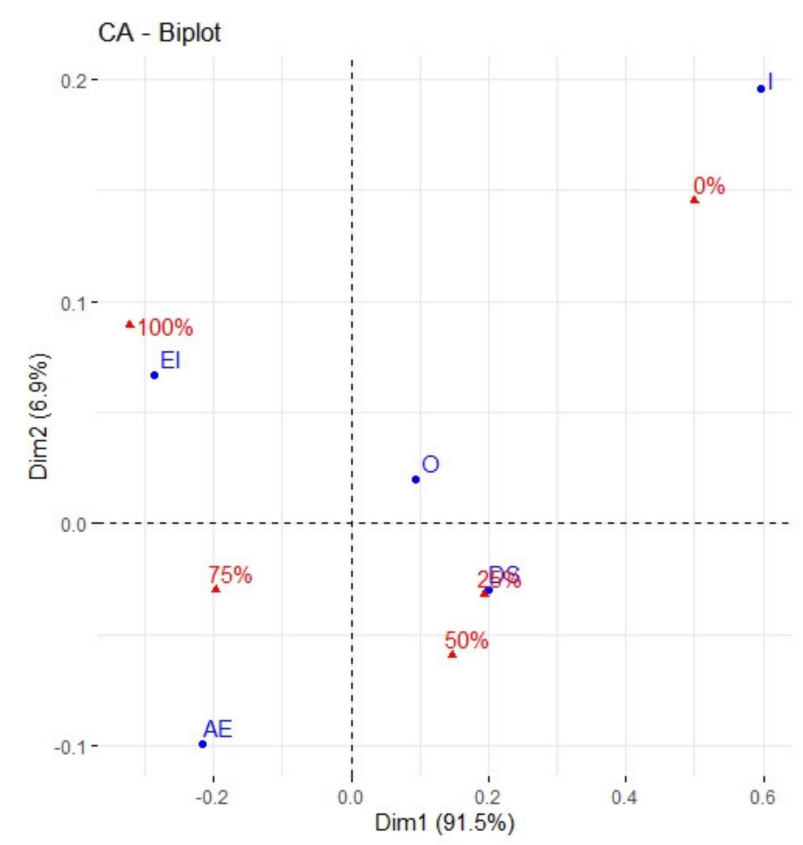

(c)

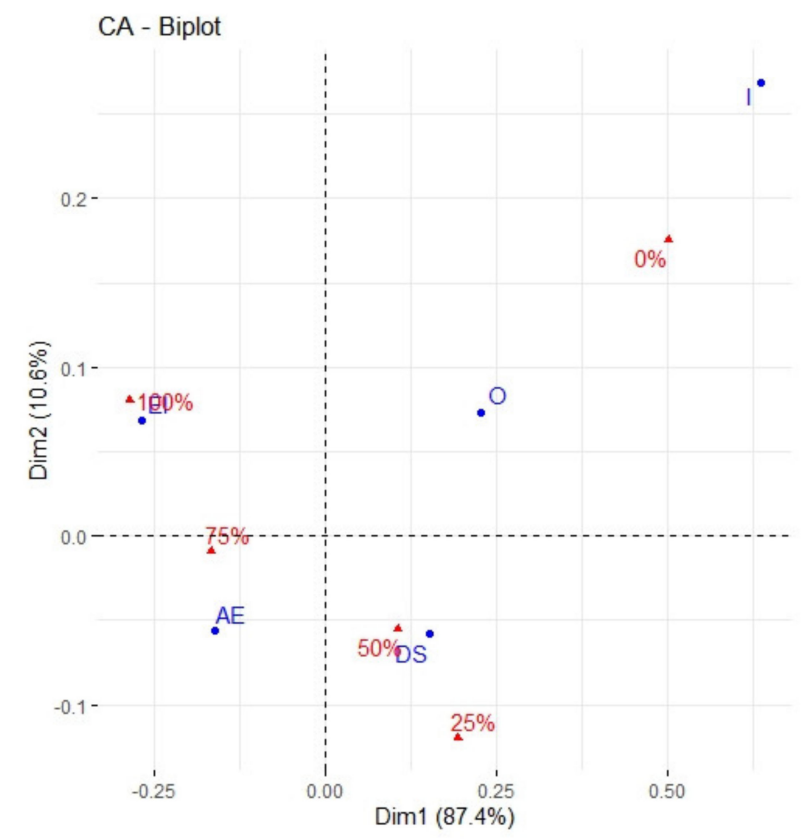

(e)

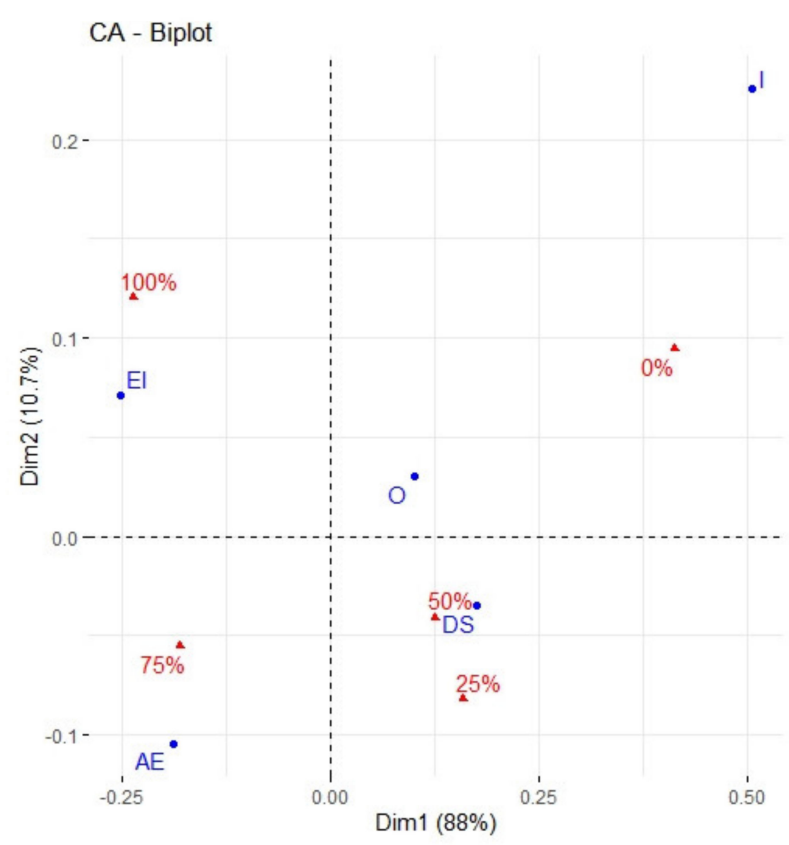

(d)

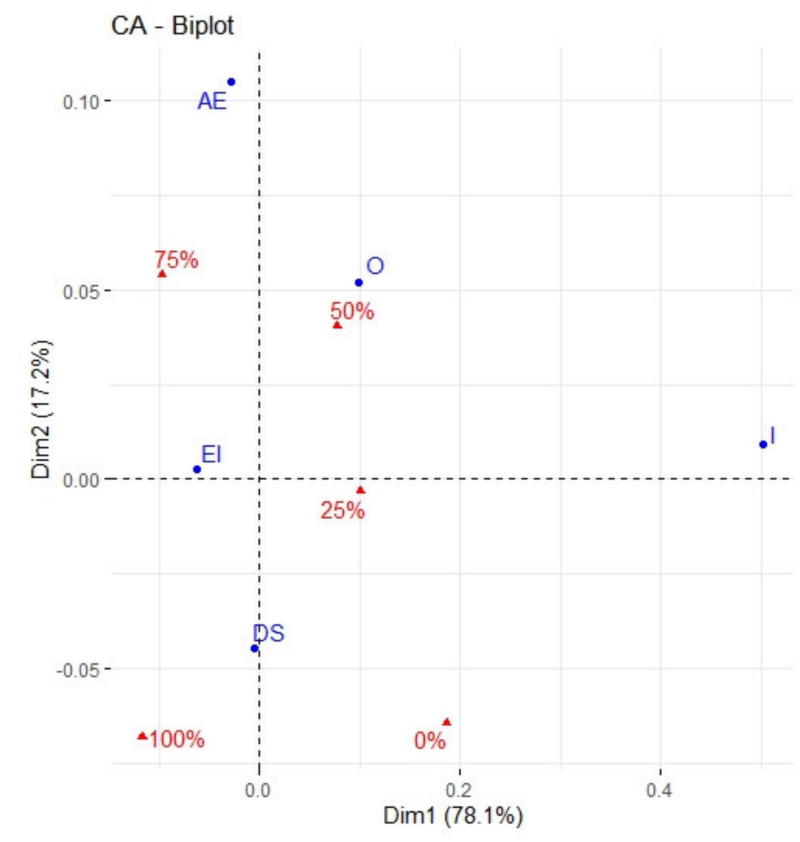

(f)

Figure 1. Correspondence maps showing the links between the 5 types of energy consumers and their declared degree of usefulness of selected types of incentives: (a) professional audit/analysis of household's energy consumption; (b) use of a dedicated application or other IT tool (e.g., a chatbot); (c) social campaigns on energy (advertising spots, billboards); (d) obtaining repayable funding for investments related to energy saving or renewable energy sources (RES); (e) keeping up with the green trend; (f) increased energy prices.

The results of Correspondence Analysis (shown on the 6 maps presented by Figure 1) indicate the following relationships:

- Ecological Idealists are people who declare very high usefulness $(100 \%)$ of almost all incentives. For them, the strongest motivation to save energy is the need to follow the green trend, because the point representing this respondent (EI) is closest to the 
point showing $100 \%$ of the incentive's impact (Figure 1e). Only the energy price increase is not perceived as a strong motivator. The points representing the EI and 100\% categories are relatively far apart (Figure 1f);

- Aspiring Ecologists mostly indicate the quite high (75\%) helpfulness and effectiveness of the studied instruments;

- Dedicated Savers are energy users who generally indicate average $(50 \%)$ or low $(25 \%)$ usefulness of the studied incentives. As shown by the arrangement of points presented in Figure $1 \mathrm{f}$ (in this case the point representing "DS" is closest to the point representing "100\%"), only an increase in energy prices can strongly motivate them to save;

- In most of the examined cases, the Opportunists also declared average $(50 \%)$ or low (25\%) effectiveness of each type of incentive. However, it is noteworthy that in the case of the incentive concerning the use of IT tools and the incentive in the form of energy price changes, the Opportunist segment has shown interest more often than in cases of other instruments (The point showing the segment is located very close to the point showing $50 \%$-Figure $1 \mathrm{~b}$ );

- According to the authors' predictions and the assumptions of the created segmentation, Indifferent consumers are not interested in energy savings, which is why they evaluate very poorly $(0 \%)$ most of the presented instruments.

\subsection{Extracting Incentives Types by Identifying Latent Factors}

A large number of studied incentives, significantly related to behavioural types of energy consumers, prompted the authors to conduct further analysis. First of all, the aim was to group the studied instruments and to identify latent factors on the basis of directly observable ones. Such research goals coincide with the idea of Principal Component Analysis, which is why this particular method was used in the second stage of the study. It should be emphasised that conducting the Principal Component Analysis was methodologically correct due to the extended scale of measurement (0-100\%) in the survey questionnaire.

Principal Component Analysis is performed in several steps. First of all, it was checked, using appropriate measures, which variables could be used in the analysis. For this purpose, the Kaiser-Meyer-Olkin measure $(K M O)$ was calculated:

$$
K M O=0.94
$$

High values of this measure indicated that all variables representing the considered incentives should be included in the study. In the next step, the number of latent factors to be formed as combinations of those directly observable was determined using one of the available criteria. In this case, the criterion of explained variance was used. Assuming that at least $60 \%$ of the variability of the original features should be explained by the new factors obtained, it was decided to create four new variables. Appropriate interpretation of these factors was possible due to the use of Varimax rotation. Finally, a factor loading matrix was obtained, indicating how strongly correlated the observed incentives are with the created, new factors (Table 2).

Table 2. Factor loading matrix.

\begin{tabular}{|c|c|c|c|c|}
\hline \multirow{2}{*}{ Incentives } & \multicolumn{4}{|c|}{ Factors } \\
\hline & 1 & 2 & 3 & 4 \\
\hline Social campaigns on energy (advertising spots, billboards) & 0.725 & 0.127 & 0.201 & 0.045 \\
\hline $\begin{array}{c}\text { Promotional and informational material from energy companies (leaflets, } \\
\text { brochures, websites) }\end{array}$ & 0.715 & 0.061 & 0.226 & 0.076 \\
\hline Information obtained from the Internet and social media & 0.705 & 0.050 & 0.223 & 0.098 \\
\hline Use of a dedicated application or other IT tool (e.g., a chatbot) & 0.684 & 0.313 & 0.049 & 0.041 \\
\hline Initiatives within local communities aimed at energy saving & 0.666 & 0.196 & 0.259 & 0.000 \\
\hline Training or other form of organised education & 0.665 & 0.313 & 0.087 & -0.031 \\
\hline $\begin{array}{c}\text { Regular updates on energy consumption provided by your energy supplier (website, } \\
\text { phone, direct contact) }\end{array}$ & 0.649 & 0.140 & 0.215 & 0.070 \\
\hline Professional audit/analysis of your household's energy consumption & 0.642 & 0.214 & 0.158 & 0.072 \\
\hline
\end{tabular}


Table 2. Cont

\begin{tabular}{|c|c|c|c|c|}
\hline \multirow{2}{*}{ Incentives } & \multicolumn{4}{|c|}{ Factors } \\
\hline & 1 & 2 & 3 & 4 \\
\hline Obtaining non-repayable funding for investments related to energy saving or RES & 0.150 & 0.789 & 0.185 & 0.087 \\
\hline Obtaining repayable funding for investments related to energy saving or RES & 0.281 & 0.722 & 0.131 & 0.026 \\
\hline Energy self-sufficiency as a result of being an energy producer & 0.208 & 0.699 & 0.307 & 0.076 \\
\hline $\begin{array}{l}\text { Social influence creating the need for pro-environmental behaviours incorporated as } \\
\text { an internal need for environmental protection }\end{array}$ & 0.224 & 0.157 & 0.798 & 0.017 \\
\hline $\begin{array}{c}\text { Care about my and my family's health translating into care for the quality of } \\
\text { the environment }\end{array}$ & 0.219 & 0.231 & 0.755 & 0.055 \\
\hline Keeping up with the green trend & 0.318 & 0.219 & 0.613 & 0.065 \\
\hline Increased energy prices & 0.126 & 0.123 & 0.080 & 0.976 \\
\hline
\end{tabular}

High values of factor loadings, shown in bold in Table 2, indicate which variables (observable incentives) load each factor.

1. The first factor is most strongly correlated with incentives for energy saving, which are associated with providing information. These are materials provided in a traditional way (e.g., promotional and informational material, social campaigns), through the Internet, via social media or other IT tools (dedicated application, chatbots), and through direct contact during training (e.g., professional audit, training, or another form of organised education). Therefore, the first factor that links these types of incentives was called "Information and Knowledge" by authors;

2. The second obtained factor is associated with motivating energy consumers through financial incentives, enabling them to make investments that allow for savings in the long term. As the obtaining repayable and non-repayable funds (e.g., for installing renewable energy sources, thermo-modernisation), as well as the possibility of producing energy themselves, are the incentives loading this factor, it was called "Investments";

3. The third factor is mainly defined by motivators, which determine the influence of the external environment on promoting and shaping pro-environmental attitudes. They are often a manifestation of peer pressure from the closest people (family, friends, and social groups to which consumers belong) or can be inspired by social trends. Concern for one's own and one's family's health is also seen here as an external stimulus motivating behavioural change. This factor has been called "Social Influence".

4. The last factor extracted through PCA is the "Energy Price". It is worth noting that in this case, it is the primary observable variable and not a combination of several different incentives. The potential increase in energy prices is such an important and different stimulus to undertake energy saving measures that this variable was singled out as a separate factor when the analysis was performed.

\subsection{Comparison of Factors Representing Four Types of Incentives}

Correspondence Analysis presented in Section 4.1 showed that the strength of the impact of the individual incentives depends on the behavioural type of the energy user. This raises the question of whether this conclusion can also be confirmed for the obtained latent factors. In other words, whether consumers' susceptibility to:

- information and knowledge about energy saving methods,

- possibilities of obtaining financing for investments in environmentally-friendly solutions,

- pressure from social groups in this regard,

- increases in energy prices,

differs between particular segments. The Kruskal-Wallis test with post-hoc analysis was used to test the significance of the mentioned differences. However, this study was conducted on new variables created as the so-called summary scales. This approach was used because the factors extracted in Section 4.2 by means of Principal Component Analysis were combinations of all the incentives and motivators considered. This means that although these 
individual factors ("Information and Knowledge", "Investments", "Social Influence" and "Energy Price") were most dependent on the specific type of instruments, their values were also influenced by the other incentives, which could distort the results of further analyses.

In order to construct the summary scales, the information obtained during the PCA was used. Thus, 4 new variables were created equivalents of the latent factors, by averaging the values of those characteristics that were most strongly correlated with these factors. This approach was previously tested by means of Reliability Analysis and the calculated value of Cronbach's alpha coefficient. In each of the examined cases (except for energy price, which was a single variable) values higher than 0.7 were obtained (Table 3), which confirms the validity of the adopted concept.

Table 3. Results of Reliability Analysis.

\begin{tabular}{cccc}
\hline Factor & Information and Knowledge & Investments & Social Influence \\
\hline $\begin{array}{c}\text { Cronbach's alpha } \\
\text { coefficient }\end{array}$ & 0.873 & 0.731 & 0.720 \\
\hline
\end{tabular}

In the next step, the Kruskal-Wallis test was performed, which confirmed that the susceptibility to each type of motivation ("Knowledge", "Investments", "Social Influence", and "Energy Price") depends on the behavioural type of the energy consumer (Table 4).

Table 4. Results of Kruskal-Wallis test.

\begin{tabular}{ccccc}
\hline Factor & $\begin{array}{c}\text { Information and } \\
\text { Knowledge }\end{array}$ & Investments & Social Influence & Energy Price \\
\hline Kruskal-Wallis & $414.1^{* * *}$ & $245.6^{* * *}$ & $391.4^{* * *}$ & $50.2^{* * *}$ \\
\hline Note: Statistical significance at: ${ }^{* * *} \alpha=0.001$. & & &
\end{tabular}

Post-hoc analysis, allowing a pair-wise comparison of different segments of energy users, provided an interesting conclusion. It turned out that the results obtained for factors representing "Information and Knowledge", "Investments", and "Social Influence" were somewhat similar. In each of the three cases, only Dedicated Savers and Opportunists did not differ significantly in their evaluation of the effectiveness of the studied incentives (Table 5). Moreover, as the box plots show (Figure 2), the most susceptible to incentives based on information and knowledge, investments, and social pressure are the Ecological Idealists. Slightly lower values were observed for Aspiring Ecologists. As it is already known, Dedicated Savers rated the examined factors in the same way as Opportunists, and in both cases, those incentives have lower influence than on respondents classified as both Ecological types. The lowest ratings of the usefulness of the analysed incentives were declared by Indifferent respondents.

Table 5. Results of Post-hoc tests.

\begin{tabular}{|c|c|c|c|c|c|c|c|c|}
\hline \multirow{2}{*}{$\begin{array}{c}\begin{array}{c}\text { Sample } \\
\text { 1/Sample } 2\end{array} \\
\text { I/O }\end{array}$} & \multicolumn{2}{|c|}{ Information and Knowledge } & \multicolumn{2}{|c|}{ Investments } & \multicolumn{2}{|c|}{ Social Influence } & \multicolumn{2}{|c|}{ Energy Price } \\
\hline & 675.7 & $* * *$ & 468.8 & $* * *$ & 472.4 & ** & 462.9 & ** \\
\hline $\mathrm{I} / \mathrm{DS}$ & 518.7 & $* * *$ & 514.7 & $* * *$ & 652.3 & $* * *$ & 608.7 & $* * *$ \\
\hline $\mathrm{I} / \mathrm{AE}$ & 1053.4 & $* * *$ & 794.7 & $* * *$ & 942.1 & $* * *$ & 605.5 & $* * *$ \\
\hline $\mathrm{I} / \mathrm{EI}$ & 1300.4 & $* * *$ & 1095.9 & $* * *$ & 1377.7 & $* * *$ & 656.0 & $* * *$ \\
\hline $\mathrm{O} / \mathrm{DS}$ & 157.0 & & 45.9 & & 179.9 & & 145.8 & \\
\hline $\mathrm{O} / \mathrm{AE}$ & 377.7 & $* *$ & 325.5 & ** & 469.6 & $* *$ & 142.6 & \\
\hline $\mathrm{O} / \mathrm{EI}$ & 624.7 & $* * *$ & 627.1 & $* * *$ & 905.2 & $* * *$ & 193.1 & \\
\hline $\mathrm{DS} / \mathrm{AE}$ & 534.7 & $* * *$ & 279.6 & $* * *$ & 289.8 & $* * *$ & -3.2 & \\
\hline DS/EI & 781.8 & $* * *$ & 581.2 & $* * *$ & 725.4 & $* * *$ & 47.3 & \\
\hline $\mathrm{AE} / \mathrm{EI}$ & 247.0 & $* * *$ & 301.6 & $* * *$ & 435.6 & $* * *$ & 50.5 & \\
\hline
\end{tabular}




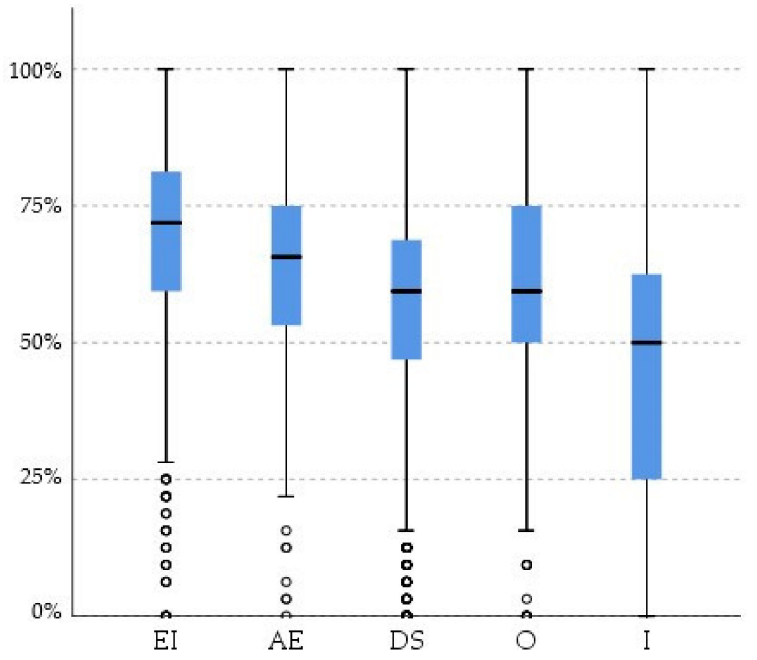

(a)

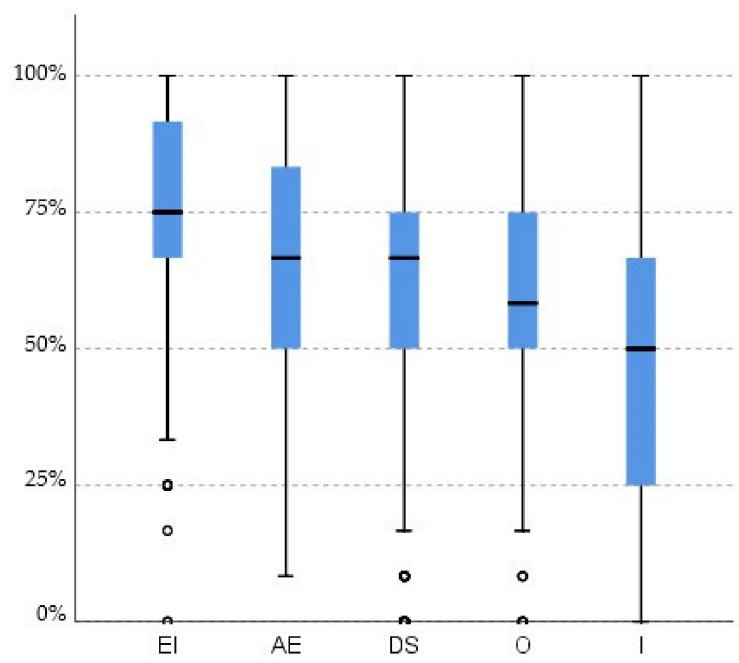

(c)

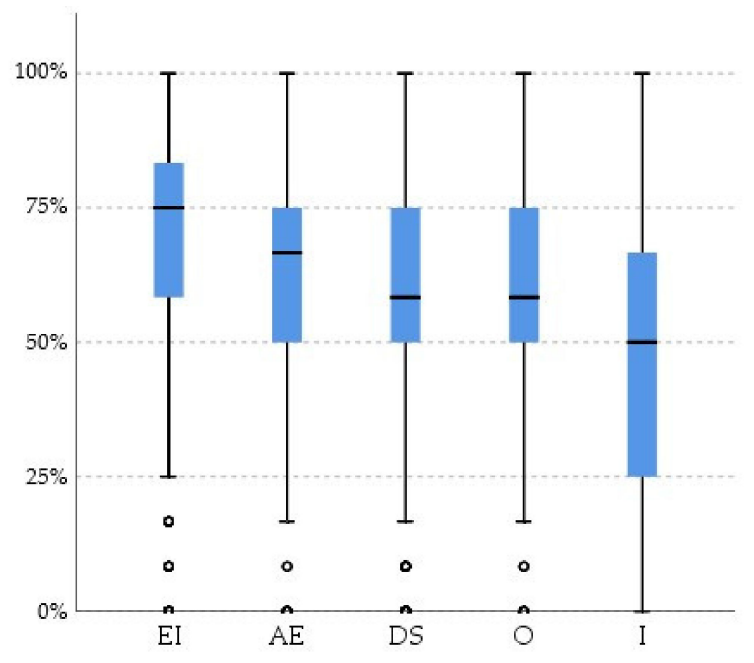

(b)

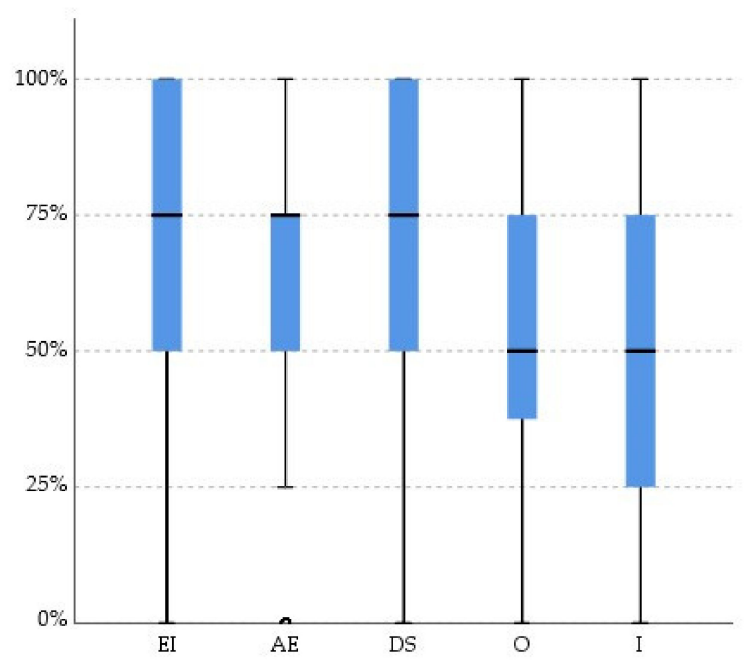

(d)

Figure 2. Box plots showing the distribution of the studied factors: (a) Information and Knowledge; (b) Investments; (c) Social Influence; (d) Energy Price, by 5 behavioural types.

It is worth noting that an increase in energy prices, as the motivator, affects in a similar, strong way pro-ecological behaviours of almost all respondents. Only Indifferent respondents assess this instrument significantly lower (Table 5, Figure 2).

\section{Discussion}

When interpreting the obtained results, it was observed that the particular behavioural types, identified as a result of the segmentation created by the authors, declared almost equal strength of influence of each of the examined incentives and motivators aimed at shaping pro-ecological and energy savings attitudes. One might expect that certain incentives, or even latent factors derived from factor analysis (PCA), might prove to be more attractive and motivating for different types of consumers than others, e.g., financial more than informational, or related to social influence (peer pressure) more than financial. Considering the characteristics of the assumed a priori segments classified as ecological ones, especially for the Aspiring Ecologist, external stimuli, consistent with the professed values, may seem to be the most attractive, i.e.,: the influence of social groups, ecological 
trends; perhaps the actions of regulatory instruments. For the Dedicated Saver segment, on the other hand, motivators based on financial aspects would seem to be the best. However, the analysis conducted by the authors did not show such dependencies. It is difficult to relate the obtained result to the works of other researchers, because in the literature, to the best of the authors' knowledge, there are no studies of the consumer profile (especially behavioural) linking them with the impact (or rather its strength) of individual interventions. However, numerous studies $[99,100]$ clearly indicate that human behaviour is one of the most important factors shaping individual energy consumption. Therefore, it is important to search for effective ways to motivate societies towards environmentally friendly and energy-efficient behaviours [101-103]. However, researchers have so far been unable to come to clear conclusions about which individual energy interventions are the most effective $[9,104]$.

The test results analysed by the authors indicated a very important dependence: there is a link between the behavioural type and the effect of all external incentives and motivators. Namely, the observed dependency, and therefore the effectiveness in motivating pro-environmental activities, is the stronger, in the case of each of the incentives, the greater the pro-environmental intrinsic motivation declared by the respondent. The Ecological Idealist type is the most sensitive to all kinds of incentives and external stimuli motivating them to optimise their energy consumption even further. It would seem that in the case of this segment additional incentives are not necessary, but according to the authors, the interest of people with high environmental awareness should be maintained and such people should also be rewarded for their pro-ecological behaviours [82]. As Steg et al. [24] point out, information is effective if it resonates with consumers' intrinsic values and Taufik et al. [105] note that individuals are more likely to act in a pro-environmental manner under the influence of 'valuation by feeling'. Anticipating the positive feeling (satisfaction) evoked by acting for a good cause, individuals are more likely to act in an environmentally friendly way than by cost calculations and perceived material benefits [105]. The stronger the predicted satisfaction about their actions, the more motivated people were to act proecologically. Therefore, as Cattaneo [19] rightly points out, external incentives, especially information interventions, highlighting in their campaigns the selfless, social aspects of pro-ecological actions, should target people who care very much about the environment.

The Aspiring Ecologist, according to the analysis, determined the strength of influence of almost all the examined incentives at the level of $75 \%$ and is, as it were, situated between EI and DS. This is confirmed by the authors' Kruskal-Wallis test and post-hoc analysis. It may result from lower, than in the case of Ecological Idealist, degree of assimilation of ecological and pro-environmental values or unwillingness to admit to being influenced by external factors. Moreover, the greater susceptibility of this type of consumer to financial incentives, compared to the DS segment, may indicate the need to make the appropriate investments, especially under the influence of environmental suggestions and the increasingly popular green trends spreading through various sectors of the economy. It should be remembered that people assigned to the AE segment, when taking action, look at their immediate environment as if into a mirror, often comparing themselves to people they consider to be authorities or trendsetters. This is a consumer who is driven to act by an intrinsic need to follow trends and belong to a selected group. At the same time, this type of consumer is more inclined to accept recommendations and advice from others than to look for pro-environmental solutions on their own. The obtained results confirm those of other researchers [35,104,106-111] who analysed, among other things, social influence, peer pressure, and actions undertaken under local/civic initiatives. The main findings from these studies indicate, for example, that peer pressure is considered highly motivating regardless of the channel through which it is communicated, i.e., offline or online [67]; interventions are more effective when their social impact and peer pressure is strong, especially when energy conservation is seen as a socially desirable practice [108]. Social norms can effectively induce behaviour change [111] and people who share information about how to save energy are more likely to save themselves [112]. Slot et al. (2018) [113] 
emphasised that the actions taken under pro-savings initiatives usually go hand in hand with energy savings and a sustainable lifestyle. Iweka et al. [22] noted that communitybased interventions can reach more people as long as everyone in the group is cooperative and displays pro-environmental attitudes. Asensio and Delmas [114] investigated that health-related information can change behavioural patterns in the long term.

Another interesting observation from the analysis is that the Dedicated Saver is only half as sensitive to both financial and non-financial incentives (50\% impact strength, sometimes $25 \%$ ) as the ecological segments. According to the analysis, although this segment is guided in its actions by an internal need to save money and manage its budget rationally, as the results show, external financial stimuli are not in this case 100 percent effective. This may be the result of investments already made in energy-use optimisation solutions, e.g., RES, which reduces expenditure and allows for better management of the household's energy consumption. Hence, this segment may not feel a further need to raise additional funds for such measures. The authors also believe that the relatively low impact of financial incentives may be due to the difficult material situation in which this type of consumer may be and to their inability to respond to financial incentives. The socio-economic characteristics carried out in our previous study [4] indicates that the DS segment's representatives are usually older, retired people with a per capita income of up to 0.7 of the average earnings. The Dedicated Saver may also find these incentives unattractive, as they are focused on short-term optimisation measures and do not see their long-term benefits. Especially since, as the results show, they are more sensitive to changes in energy prices than to other interventions, which may confirm the authors' interpretation.

The price of energy is a quite specific factor here, which was singled out as a separate factor during the PCA analysis. It can be assumed that the high response to this stimulus of almost all segments (except I) is due to the ease of interpretation of the costs and benefits of the changes made. Of all the financial incentives (subsidies, loans, tax breaks, etc.), energy price changes are the easiest to understand and the most visible. Even for the Opportunist segment (which also declares to be more influenced by this factor than the others), price changes are easy to observe, do not require effort and high involvement which is not characteristic of this type of consumer. Furthermore, price changes are the most common information on energy consumption appearing in media messages and public discussions, on one hand, presented as an incentive and on the other as a barrier for undertaking pro-efficiency actions. The authors believe that the price of energy is a common factor for people sensitive to other financial incentives, further inducing them to invest to optimise energy consumption and stimulate long-term planning. However, price as an incentive also works for people with lower incomes, where the material situation does not allow for expensive investments. In the short term, under the influence of price changes, such consumers also change their behaviours, sometimes only temporarily, in order to neutralise the effects of energy price increases. Very often such behaviour is limited to simple actions such as switching off lights or simply reducing consumption.

The results also confirmed the segmentation assumptions concerning consumers classified as Opportunists. According to the analysis, this type of people, guided in their actions mainly by their reluctance to reduce comfort, are relatively uninvolved in environmentally friendly behaviours. This is confirmed by their low susceptibility to the types of incentives studied. Opportunists can be pro-ecological when actions are easy and convenient to apply. The observed higher level of susceptibility to the incentives in the form of an IT tool dedicated to informing and managing energy, e.g., a chat-bot, a dedicated app, or other smart-home solutions, is in line with the assumptions of this segment. Ease and clarity of feedback is a key success factor in this case. This is confirmed by research $[80,83,86,115,116]$. Joachain and Klopfert [80] combine the advantages of feedback from smart metering with an incentive system based on "complementary currency", concluding that it works well to promote curtailment behaviours and serves to increase awareness, knowledge, and user engagement. Weber et al. [81] indicate that feedback and financial motivation, work more effectively in combination than separately. Kim et al. [83] note a change in be- 
haviours with the use of personalised 'push notifications' in a smartphone application. They also recommend increasing the interactivity of communication between users and service providers, claiming that this effectively triggers user energy-saving behaviours. Additionally, $[86,117,118]$ highlight the positive role of ICTs in shaping and reinforcing energy-saving behaviours in households by showing feedback about achieved financial savings or other information such as carbon footprint. Providing real-time information on energy consumption $[117,119]$ as well as the type and method of delivery is important for changing user behaviours [118]. According to the assumptions, people assigned to the Opportunist segment, although behaving pro-ecologically, do so very occasionally, irregularly, and show satisfaction with their low levels of commitment and very often do not want to change. However, they are also susceptible to influence (all the more so if the information is provided in an easy and enjoyable manner and, what is important, does not limit their comfort). Therefore, feedback "packaged" in an appropriately attractive way, according to the authors, may play a significant role in reaching this type of people with motivating messages. Although, as argued by $[120,121]$, it is important to remember that information on energy consumption alone is not sufficiently effective. These types of stimuli should be reinforced by other instruments such as financial incentives, target setting or personal commitment.

When creating the segmentation, the authors assumed that there are people who are completely uninterested in environmental issues and do not care about their energy consumption. The resulting analysis fully confirmed this assumption and showed that such people are completely unresponsive to any external stimuli or incentive instruments. In the authors' opinion, the Indifferent segment is the most difficult to reach with a proenvironmental message, and thus to influencing change in their behaviours. Although this segment is not large, which should be evaluated positively, the question about finding effective instruments to motivate such people to reduce their energy consumption remains unanswered. We may only hope that future research will extend existing knowledge in this area and help to develop such tools which will translate into increased energy efficiency in the personal consumption sector on a more global scale. The authors perceive the search for a solution to this problem as an important requirement and direction for further research.

\section{Conclusions}

The presented paper is the result of the next stage of the authors' research on energy consumers modelling, their segmentation and comprehensive characterisation of the obtained behavioural types/profiles. At this stage, the aim of the analysis was to examine the relationship between the different consumer segments and diverse external incentives, interventions and types of instruments that promote pro-efficiency behaviours both in the long and short term. When constructing the survey questionnaire, the authors tried to take into account a broad spectrum of different types of incentives, both financial (investments; energy prices) and non-financial (information and education, influence of the external environment and societal values or trends). The study was carried out in three stages and the results of the subsequent steps formed the basis for further in-depth analyses.

The obtained results enabled reaching all set objectives and answering the posed research questions. (1) The $100 \%$ correctness of the assumptions of the authors' segmentation was confirmed by verifying once again the validity of the classification of individual consumers according to the dominant intrinsic motivation to save energy and (2) by demonstrating a significant dependency between behavioural types and the incentives and motivators studied. Furthermore, (3) it was indicated that the strength of the impact of the external incentives studied depends on the degree of internal pro-environmental motivation of the consumer. The higher the pro-environmental commitment of the consumer (belonging to a more pro-ecological segment) the higher the strength of the impact of all energy interventions. (4) The analysis made it possible to identify the latent factors that allowed grouping of the examined incentives. Surprisingly the energy price constituted a separate factor from other financial incentives. Additionally, (5) no differences in the effec- 
tiveness of particular types of incentives were found within each of the identified segments; but the effectiveness of particular types of incentives differed between particular segments. The basic conclusions that emerge from the analysis are as follows:

1. To be effective, external incentives, motivators and other intervention measures should be applied comprehensively. Preferably in the form of energy efficiency plans. Applying incentives individually may not have the desired effect and it is, therefore, advisable to combine them so that different types of incentives and instruments are used in the framework of the intervention plans.

2. Furthermore, each type of incentive should be adapted to fit the behavioural profile of the consumer. In order to achieve results in the form of behavioural changes and, consequently, obtain measurable energy savings which translate into environmental benefits in the form of reduced emissions, it is necessary to personalise particular types of interventions by tailoring them accordingly to the internal motivations and beliefs of the consumer. It is therefore of utmost importance to correctly identify these needs, attitudes and motivations and to correctly segment them so that intervention measures can be appropriately tailored.

3. It is also important to regularly check whether consumers' intrinsic motivation has not changed over time or in relation to the pro-efficiency measures or investments carried out.

4. According to the authors, in order to increase energy efficiency and shape correct social attitudes, the top-down approach-imposed by the authorities, energy suppliers, local initiatives or external environment-should be combined with a bottom-up approach, represented by an individual's internal motivation. The greatest effectiveness can be achieved when these two approaches coincide in terms of values.

The presented approach and analysis are not free from several limitations. First of all, in the construction of the survey questionnaire, the authors included questions taking into account respondents' declarative answers. The aim of the research was not to actually measure the achieved effectiveness, e.g., employing experimental methods, but to identify the potential impact of incentives on individuals in the future. Due to the limitations of the research tool's length, the questionnaire did not include all possible incentives and extrinsic motivators. After reviewing the literature on the subject, the authors tried to include in the study the widest possible range of interventions, taking into account the different types and methods of transmission, yet tools such as gamification, fiscal, or regulatory tools were missing. The authors also did not ask the respondents about their past experiences and objective limitations, e.g., the inability to apply any of the instruments due to not being able to meet the required criteria, etc. The study focused on respondents' own perceptions of the potential impact of the studied tools and all evaluations were based on this assumption.

Aware of the existing limitations, the future directions of the authors' research include extending the analysis, first of all, to include a comprehensive characterisation of the Indifferent segment, together with identifying the basic barriers to accessing this type of people and the potential difficulties in conveying the appropriate message. Examining the effectiveness of the provided information and personalised recommendations on energy optimisation opportunities in the opinion of representatives of individual segments also looks like a promising and interesting research direction. The authors also intend to focus on assessing the influence of social groups on particular segments and to identify similarities and differences in the approach to modern technology by different types of consumers. Furthermore, the authors recommend as a direction for future research to complement the results presented in this paper with an actual study of the effectiveness of individual intervention tools in combination with a behavioural profile of the consumer.

Author Contributions: Conceptualization, S.S., J.K.-Ł. and J.T.; methodology, S.S., J.K.-Ł. and J.T.; formal analysis, S.S., J.K.-Ł. and J.T.; investigation, S.S., J.K.-Ł. and J.T.; data curation, J.T.; writingoriginal draft preparation, S.S., J.K.-Ł. and J.T.; writing-review and editing, S.S., J.K.-Ł. and J.T.; funding acquisition, S.S. All authors have read and agreed to the published version of the manuscript. 
Funding: This research was funded by European Union's Horizon 2020 Research and Innovation Program: "Reducing energy consumption and carbon footprint by smart and sustainable use", as a part of the currently implemented project "Personalised ICT-tools for the Active Engagement of Consumers Towards Sustainable Energy. Eco-bot" under grant agreement No. 767625.

Institutional Review Board Statement: Not applicable.

Informed Consent Statement: Not applicable.

Data Availability Statement: Not applicable.

Conflicts of Interest: The authors declare no conflict of interest.

\section{Appendix A}

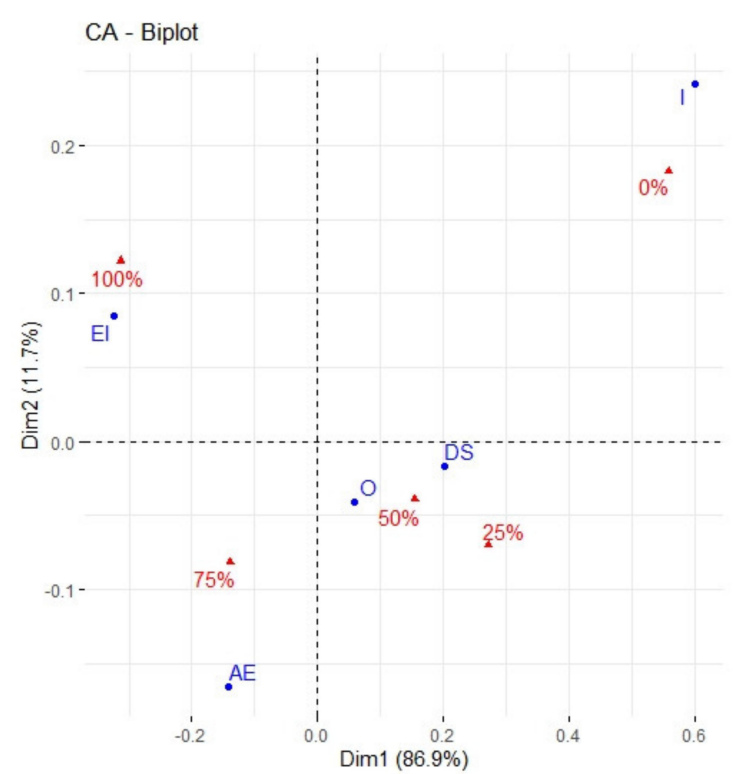

(a)

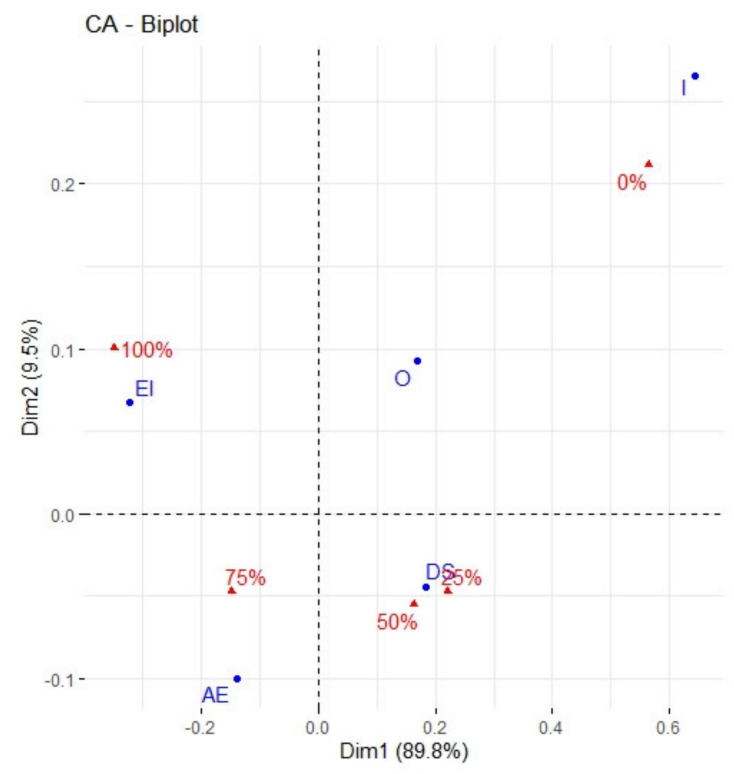

(c)

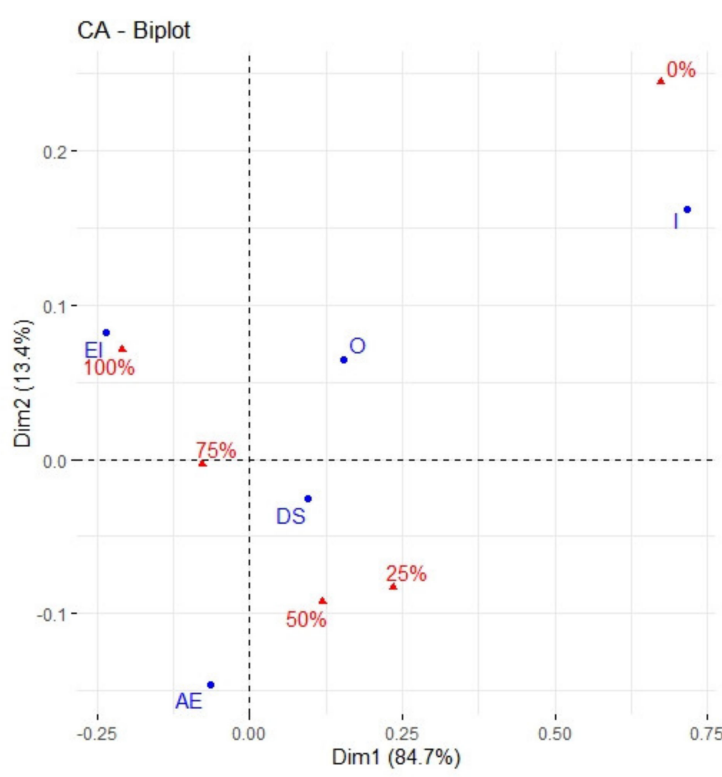

(b)

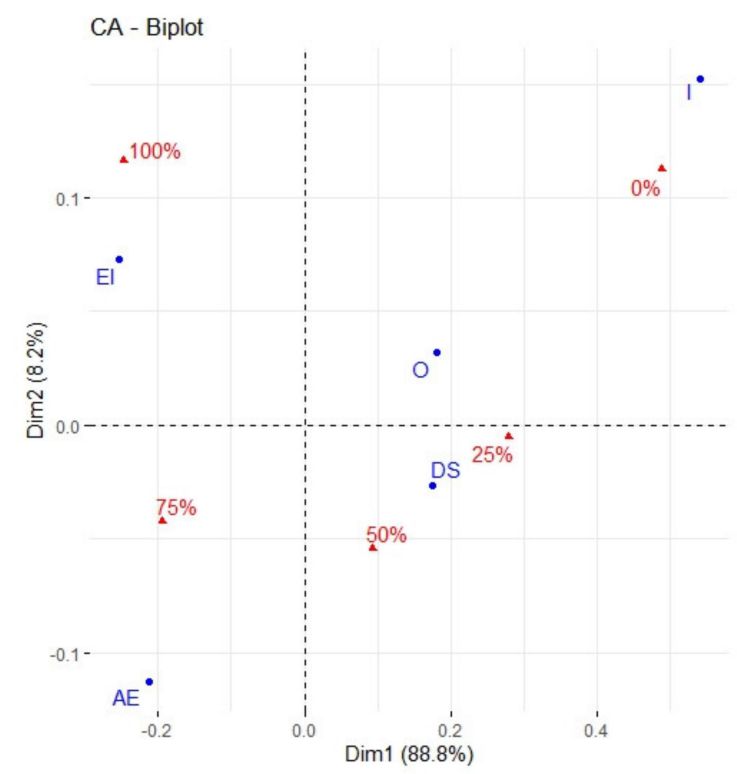

(d)

Figure A1. Cont. 


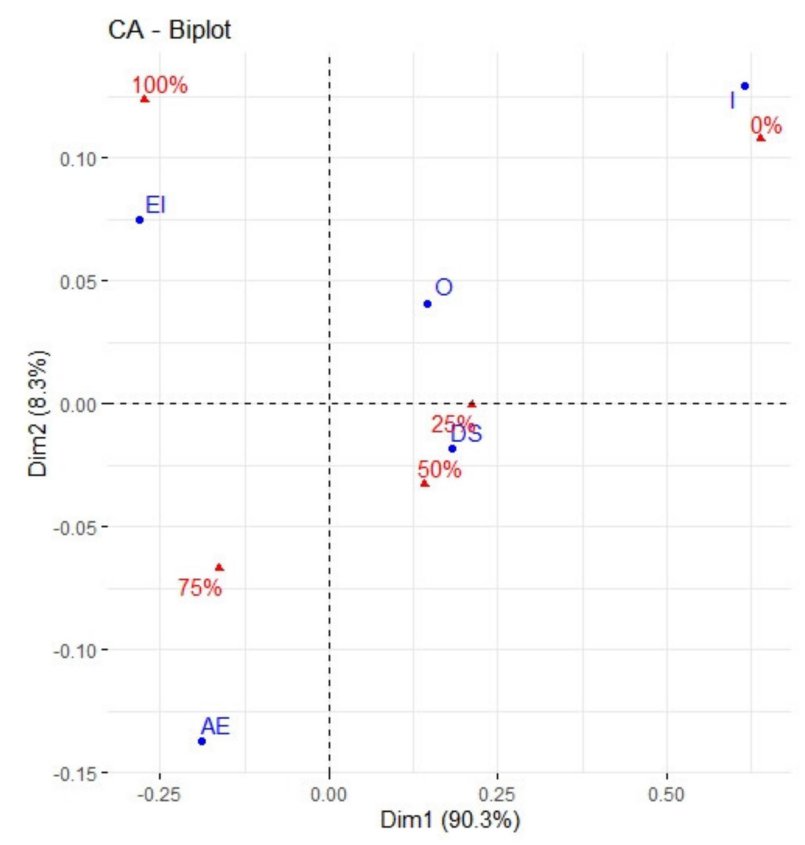

(e)

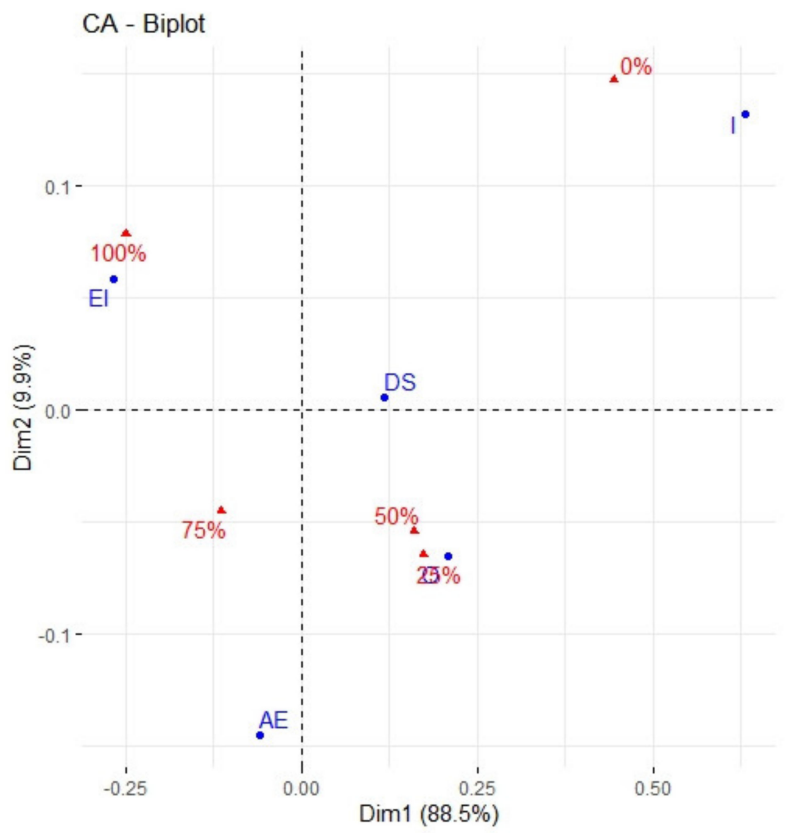

(g)

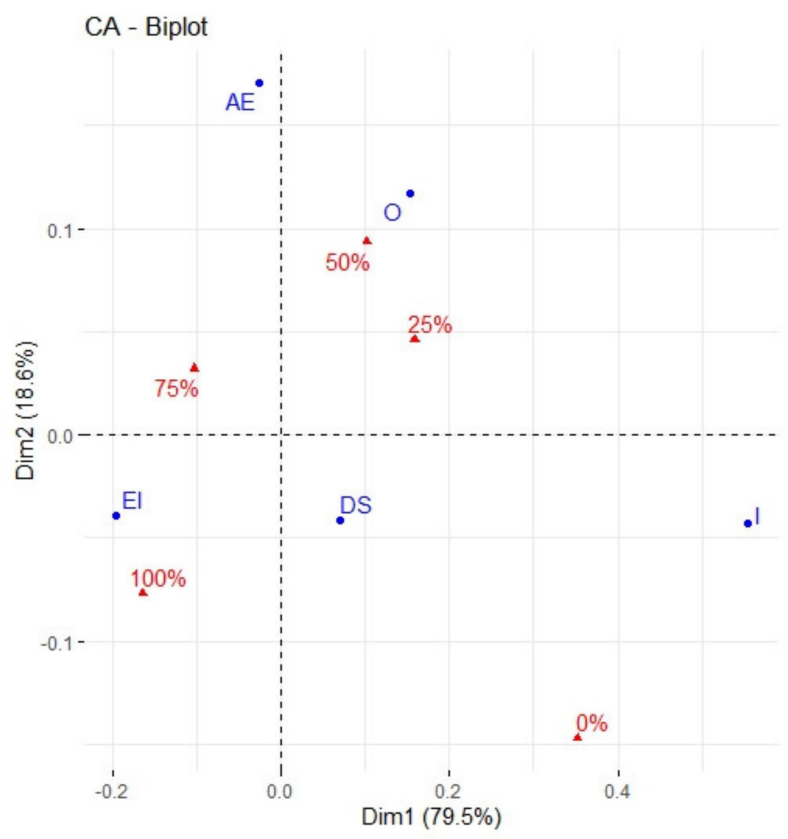

(f)

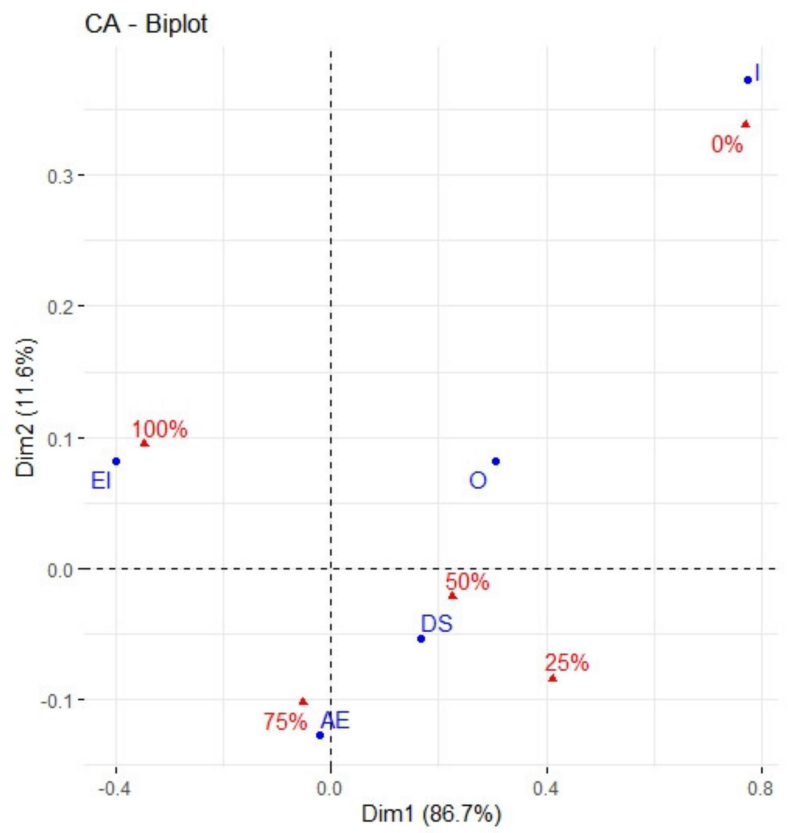

(h)

Figure A1. Cont. 


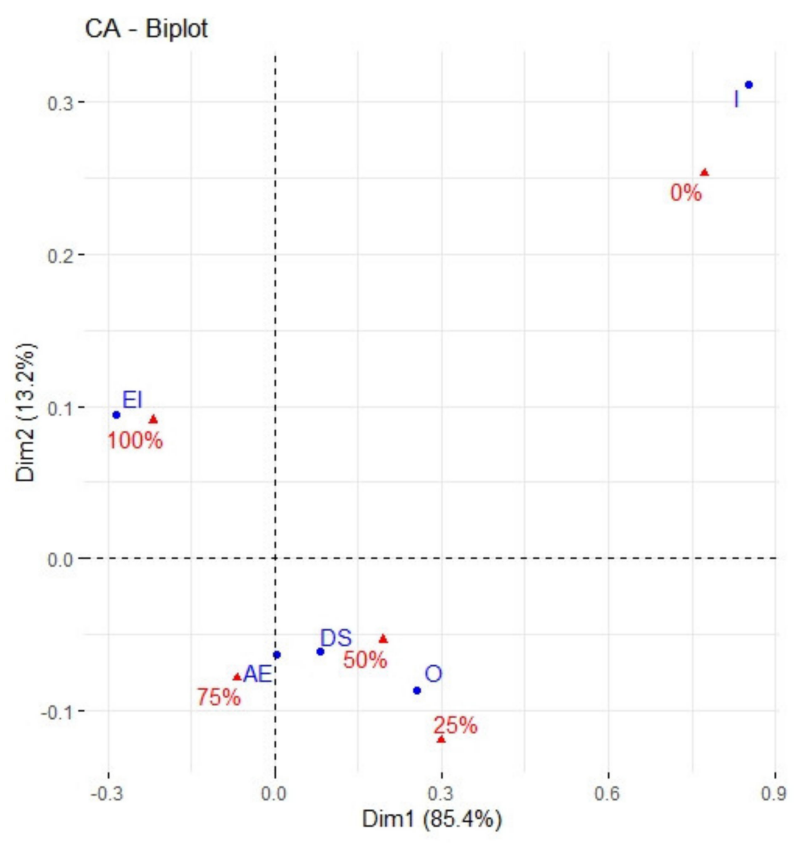

(i)

Figure A1. Correspondence maps showing the links between the 5 types of energy consumers and their declared degree of usefulness of selected types of incentives: (a) training or another form of organized education; (b) regular updates on energy consumption provided by an energy supplier (website, phone, direct contact, etc.); (c) initiatives within local communities aimed at energy saving; (d) promotional and informational material from energy companies (leaflets, brochures, websites); (e) information obtained from the Internet and social media; (f) obtaining non-repayable funding for investments related to energy saving or RES; (g) energy self-sufficiency as a result of being an energy producer; (h) social influence creating the need for pro-environmental behaviour incorporated as an internal need for environmental protection; (i) care about own and family's health translating into care for the quality of the environment.

\section{References}

1. European Commission. Fit for 55-Delivering the EU's 2030 Climate Target on the Way to Climate Neutrality; European Commission: Luxembourg, 2021; p. 15.

2. Fit for 55. 2021. Available online: https://www.consilium.europa.eu/en/policies/green-deal/eu-plan-for-a-green-transition/\# (accessed on 21 November 2021).

3. Słupik, S.; Kos-Łabędowicz, J.; Trzęsiok, J. An Innovative Approach to Energy Consumer Segmentation-A Behavioural Perspective. The Case of the Eco-Bot Project. Energies 2021, 14, 3556. [CrossRef]

4. Słupik, S.; Kos-Łabędowicz, J.; Trzęsiok, J. Are You a Typical Energy Consumer? Socioeconomic Characteristics of Behavioural Segmentation Representatives of 8 European Countries. Energies 2021, 14, 6109. [CrossRef]

5. Delivering the European Green Deal. 2021. Available online: https://ec.europa.eu/info/strategy/priorities-2019-2024/europeangreen-deal/delivering-european-green-deal_en (accessed on 21 November 2021).

6. Avgerinou, M.; Bertoldi, P.; Castellazzi, L. Trends in Data Centre Energy Consumption under the European Code of Conduct for Data Centre Energy Efficiency. Energies 2017, 10, 1470. [CrossRef]

7. Upham, P.; Oltra, C.; Boso, À. Towards a cross-paradigmatic framework of the social acceptance of energy systems. Energy Res. Soc. Sci. 2015, 8, 100-112. [CrossRef]

8. Song, Y.; Zhao, C.; Zhang, M. Does haze pollution promote the consumption of energy-saving appliances in China? An empirical study based on norm activation model. Resour. Conserv. Recycl. 2019, 145, 220-229.

9. Abrahamse, W.; Steg, L.; Vlek, C.; Rothengatter, T. A review of intervention studies aimed at household energy conservation. J. Environ. Psychol. 2005, 25, 273-291. [CrossRef]

10. Jones, R.V.; Fuertes, A.; Lomas, K.J. The socio-economic, dwelling and appliance related factors affecting electricity consumption in domestic buildings. Renew. Sustain. Energy Rev. 2015, 43, 901-917. [CrossRef]

11. Linden, S.V.; Maibach, E.; Leiserowitz, A. Improving public engagement with climate change: Five 'best practice' insights from psychological science. Perspect. Psychol. Sci. 2015, 10, 758-763. [CrossRef] [PubMed]

12. Kunreuther, H.; Weber, E.U. Aiding Decision Making to Reduce the Impacts of Climate Change. J. Consum. Policy 2014, 37, 397-411. [CrossRef] 
13. Davis, L.W.; Gertler, P.J. Contribution of air conditioning adoption to future energy use under global warming. Proc. Natl. Acad. Sci. USA 2015, 112, 5962-5967. [CrossRef] [PubMed]

14. Schultz, P.W.; Estrada, M.; Schmitt, J.; Sokoloski, R.; Silva-Send, N. Using in-home displays to provide smart meter feedback about household electricity consumption: A randomized control trial comparing kilowatts, cost, and social norms. Energy 2015, 90, 351-358. [CrossRef]

15. Brunzell, L.; Renström, R. Recommendations for revising the energy label system for dishwashers: Supporting sustainable development and usage through the interaction of energy labels, technical improvements and consumer behaviour. Energy Effic. 2020, 13, 145-155. [CrossRef]

16. Department of Energy \& Climate Change. What Works in Changing Energy-Using Behaviours in the Home? A Rapid Evidence Assessment; Department of Energy \& Climate Change: London, UK, 2012; pp. 1-127.

17. De la Rue du Can, S.; Shah, N.; Phadke, A. Country Review of Energy- Efficiency Financial Incentives in the Residential Sector. MRS Bull. 2007, 32, 389-399.

18. Martiskainen, M. Affecting Consumer Behaviour on Energy Demand Final Report to EdF Energy; Sussex Energy Group SPRU—Science and Technology Policy Research University of Sussex: Brighton, UK, 2007.

19. Cattaneo, C. Internal and external barriers to energy efficiency: Which role for policy interventions? Energy Effic. 2019, 12, 1293-1311. [CrossRef]

20. Prindle, W.; Angel, S. Customer Incentives for Energy Efficiency Through Program Offerings: National Action Plan for Energy Efficiency; ICF International, Inc.: Fairfax, VA, USA, 2010.

21. United Nations Economic Commission for Europe. Best Policy Practices Energy Efficiency; Economic Commission for Europe: Copenhagen, Denmark, 2015.

22. Iweka, O.; Liu, S.; Shukla, A.; Yan, D. Energy and behaviour at home: A review of intervention methods and practices. Energy Res. Soc. Sci. 2019, 57, 101-238. [CrossRef]

23. Markandya, A.; Labandeira, X.; Ramos, A. Policy instruments to foster energy efficiency. In Green Energy and Efficiency, Green Energy and Technology; Springer: New York, NY, USA, 2015; pp. 93-110.

24. Steg, L.; Perlaviciute, G.; Van der Werff, E. Understanding the human dimensions of a sustainable energy transition. Front. Psychol. 2015, 6, 1-17. [CrossRef]

25. Barbu, A.-D.; Griffiths, N.; Morton, G. Achieving Energy Efficiency through Behaviour Change: What Does It Take? European Environment Agency: Copenhagen, Denmark, 2013.

26. Gillingham, K.; Newell, R.; Palmer, K. Energy efficiency policies: A retrospective examination. Annu. Rev. Environ. Resour. 2006, 31, 161-192. [CrossRef]

27. Lindén, A.L.; Carlsson-Kanyama, A.; Eriksson, B. Efficient and inefficient aspects of residential energy behaviour: What are the policy instruments for change? Energy Policy 2006, 34, 1918-1927. [CrossRef]

28. Carlsson-Kanyama, A.; Lindén, A.L. Energy efficiency in residences-Challenges for women and men in the North. Energy Policy 2007, 35, 2163-2172. [CrossRef]

29. Del Mar Solà, M.; de Ayala, A.; Galarraga, I.; Escapa, M. Promoting energy efficiency at household level: A literature review. Energy Effic. 2021, 14, 6. [CrossRef]

30. Gerarden, T.D.; Newell, R.G.; Stavins, R.N. Assessing the Energy-Efficiency Gap. J. Econ. Lit. 2017, 55, 1486-1525. [CrossRef]

31. Linares, P.; Labandeira, X. Energy efficiency: Economics and policy. J. Econ. Surv. 2010, 24, 573-592. [CrossRef]

32. Filho, W.L.; Fedoruk, M.; Zahvoyska, L.; Avila, L.V. Identifying and comparing obstacles and incentives for the implementation of energy saving projects in eastern and western european countries: An exploratory study. Sustainability 2021, 13, 4944. [CrossRef]

33. Thomson, H.; Snell, C.; Bouzarovski, S. Health, well-being and energy poverty in Europe: A comparative study of 32 European countries. Int. J. Environ. Res. Public Health 2017, 14, 584. [CrossRef] [PubMed]

34. Hille, S.L. The Myth of the Unscrupulous Energy User's Dilemma: Evidence from Switzerland. J. Consum. Policy 2016, 39, 327-347. [CrossRef]

35. Ramos, A.; Gago, A.; Labandeira, X.; Linares, P. The role of information for energy efficiency in the residential sector. Energy Econ. 2015, 52, S17-S29. [CrossRef]

36. Filippini, M.; Hunt, L.C.; Zorić, J. Impact of energy policy instruments on the estimated level of underlying energy efficiency in the EU residential sector. Energy Policy 2014, 69, 73-81. [CrossRef]

37. Allcott, H.; Taubinsky, D. Evaluating behaviorally motivated policy: Experimental evidence from the lightbulb market. Am. Econ. Rev. 2015, 105, 2501-2538. [CrossRef]

38. Bertoldi, P. Are current policies promoting a change in behaviour, conservation and sufficiency? An analysis of existing policies and recommendations for new and effective policies. In Proceedings of the ECEEE 2017 Summer Study on Energy Efficiency, Hyères, France, 29 May-2 June 2017; pp. 201-211.

39. Bertoldi, P.; Rezessy, S.; Oikonomou, V. Rewarding energy savings rather than energy efficiency: Exploring the concept of a feed-in tariff for energy savings. Energy Policy 2013, 56, 526-535. [CrossRef]

40. Allcott, H. Consumers' Perceptions and Misperceptions of Energy Costs. Am. Econ. Rev. 2011, 101, 98-104. [CrossRef]

41. Villca-Pozo, M.; Gonzales-Bustos, J.P. Tax incentives to modernize the energy efficiency of the housing in Spain. Energy Policy 2019, 128, 530-538. [CrossRef] 
42. Jiménez, J.L.; Perdiguero, J.; García, C. Evaluation of subsidies programs to sell green cars: Impact on prices, quantities and efficiency. Transp. Policy 2016, 47, 105-118. [CrossRef]

43. Galarraga, I.; Abadie, L.M.; Kallbekken, S. Designing incentive schemes for promoting energy-efficient appliances: A new methodology and a case study for Spain. Energy Policy 2016, 90, 24-36. [CrossRef]

44. Gholami, R.; Emrouznejad, A.; Alnsour, Y.; Kartal, H.B.; Veselova, J. The impact of smart meter installation on attitude change towards energy consumption behavior among Northern Ireland households. J. Glob. Inf. Manag. 2020, 28, 21-37. [CrossRef]

45. Corbett, J. Using information systems to improve energy efficiency: Do smart meters make a difference? Inf. Syst. Front. 2013, 15, 573-592. [CrossRef]

46. Delmas, M.A.; Fischlein, M.; Asensio, O.I. Information strategies and energy conservation behavior: A meta-analysis of experimental studies from 1975 to 2012. Energy Policy 2013, 61, 729-739. [CrossRef]

47. Houde, S.; Aldy, J. Consumers' response to state energy efficient appliance rebate programs. Am. Econ. J. Econ. Policy 2017, 9 , 227-255. [CrossRef]

48. Sorrell, S.; Dimitropoulos, J.; Sommerville, M. Empirical estimates of the direct rebound effect: A review. Energy Policy 2009, 37, 1356-1371. [CrossRef]

49. Alberini, A.; Gans, W.; Towe, C. Free riding, upsizing, and energy efficiency incentives in Maryland homes. Energy J. 2016, 37, 259-290. [CrossRef]

50. Boomhower, J.; Davis, L.W. A credible approach for measuring inframarginal participation in energy efficiency programs. J. Public Econ. 2014, 113, 67-79. [CrossRef]

51. Mastrucci, A.; Baume, O.; Stazi, F.; Leopold, U. Estimating energy savings for the residential building stock of an entire city: A GIS-based statistical downscaling approach applied to Rotterdam. Energy Build. 2014, 75, 358-367. [CrossRef]

52. Bjørneboe, M.G.; Svendsen, S.; Heller, A. Initiatives for the energy renovation of single-family houses in Denmark evaluated on the basis of barriers and motivators. Energy Build. 2018, 167, 347-358. [CrossRef]

53. Fisk, W.J.; Singer, B.C.; Chan, W.R. Association of residential energy efficiency retrofits with indoor environmental quality, comfort, and health: A review of empirical data. Build. Environ. 2020, 180, 107067. [CrossRef]

54. Sardianou, E.; Genoudi, P. Which factors affect the willingness of consumers to adopt renewable energies? Renew. Energy 2013, 57, 1-4. [CrossRef]

55. Stigka, E.K.; Paravantis, J.A.; Mihalakakou, G.K. Social acceptance of renewable energy sources: A review of contingent valuation applications. Renew. Sustain. Energy Rev. 2014, 32, 100-106. [CrossRef]

56. Gonzalez-Caceres, A.; Lassen, A.K.; Nielsen, T.R. Barriers and challenges of the recommendation list of measures under the EPBD scheme: A critical review. Energy Build. 2020, 223, 110065. [CrossRef]

57. Ward, D.O.; Clark, C.D.; Jensen, K.L.; Yen, S.T.; Russell, C.S. Factors influencing willingness-to-pay for the Energy Star ${ }^{\circledR} l a b e l$. Energy Policy 2011, 39, 1450-1458. [CrossRef]

58. Girod, B.; Stucki, T.; Woerter, M. How do policies for efficient energy use in the household sector induce energy-efficiency innovation? An evaluation of European countries. Energy Policy 2017, 103, 223-237.

59. Brucal, A.; Roberts, M.J. Do energy efficiency standards hurt consumers? Evidence from household appliance sales. J. Environ. Econ. Manag. 2019, 96, 88-107.

60. Taylor, N.W.; Jones, P.H.; Kipp, M.J. Targeting utility customers to improve energy savings from conservation and efficiency programs. Appl. Energy 2014, 115, 25-36. [CrossRef]

61. Iwasaki, S. Using Eco-Home Diagnosis to reduce household energy consumption: A case study on behavioral changes in Fukuoka Prefecture, Japan. Energy Policy 2019, 132, 893-900. [CrossRef]

62. McHenry, M.P. Technical and governance considerations for advanced metering infrastructure/smart meters: Technology, security, uncertainty, costs, benefits, and risks. Energy Policy 2013, 59, 834-842. [CrossRef]

63. Chou, J.S.; Yutami, I.G.A.N. Smart meter adoption and deployment strategy for residential buildings in Indonesia. Appl. Energy 2014, 128, 336-349. [CrossRef]

64. Nilsson, A.; Wester, M.; Lazarevic, D.; Brandt, N. Smart homes, home energy management systems and real-time feedback: Lessons for influencing household energy consumption from a Swedish field study. Energy Build. 2018, 179, 15-25. [CrossRef]

65. Zeng, L.; Yu, Y.; Li, J. China's Promoting Energy-Efficient Products for the Benefit of the People Program in 2012: Results and analysis of the consumer impact study. Appl. Energy 2014, 133, 22-32. [CrossRef]

66. Xu, Q.; Lu, Y.; Hwang, B.G.; Kua, H.W. Reducing residential energy consumption through a marketized behavioral intervention: The approach of Household Energy Saving Option (HESO). Energy Build. 2021, 232, 110621. [CrossRef]

67. Spandagos, C.; Baark, E.; Ng, T.L.; Yarime, M. Social influence and economic intervention policies to save energy at home: Critical questions for the new decade and evidence from air-condition use. Renew. Sustain. Energy Rev. 2021, 143, 110915. [CrossRef]

68. Quaglione, D.; Cassetta, E.; Crociata, A.; Sarra, A. Exploring additional determinants of energy-saving behaviour: The influence of individuals' participation in cultural activities. Energy Policy 2017, 108, 503-511. [CrossRef]

69. Wang, B.; Wang, X.; Guo, D.; Zhang, B.; Wang, Z. Analysis of factors influencing residents' habitual energy-saving behaviour based on NAM and TPB models: Egoism or altruism? Energy Policy 2018, 116, 68-77. [CrossRef]

70. Naderi, I. I'm nice, therefore I go green: An investigation of pro-environmentalism in communal narcissists. J. Environ. Psychol. 2018, 59, 54-64. [CrossRef] 
71. Caferra, R.; Colasante, A.; Morone, A. The less you burn, the more we earn: The role of social and political trust on energy-saving behaviour in Europe. Energy Res. Soc. Sci. 2021, 71, 101812. [CrossRef]

72. Ayres, I.; Raseman, S.; Shih, A. Evidence from Two Large Field Experiments that Peer Comparison Feedback Can Reduce Residential Energy Usage. J. Law Econ. Organ. 2013, 29, 992-1022. [CrossRef]

73. Eco-Bot. 2021. Available online: http:/ / eco-bot.eu/ (accessed on 21 November 2021).

74. Vassileva, I.; Campillo, J. Increasing energy efficiency in low-income households through targeting awareness and behavioral change. Renew. Energy 2014, 67, 59-63. [CrossRef]

75. Mi, L.; Qiao, L.; Du, S.; Xu, T.; Gan, X.; Wang, W.; Yu, X. Evaluating the effect of eight customized information strategies on urban households' electricity saving: A field experiment in China. Sustain. Cities Soc. 2020, 62, 102344. [CrossRef]

76. Diaz-Rainey, I.; Ashton, J.K. Investment inefficiency and the adoption of eco-innovations: The case of household energy efficiency technologies. Energy Policy 2015, 82, 105-117. [CrossRef]

77. Van den Broek, K.L.; Walker, I. Exploring the perceptions of drivers of energy behaviour. Energy Policy 2019, 129, 1297-1305. [CrossRef]

78. Steinhorst, J.; Matthies, E. Monetary or environmental appeals for saving electricity?-Potentials for spillover on low carbon policy acceptability. Energy Policy 2016, 93, 335-344.

79. Martínez-Espiñeira, R.; García-Valiñas, M.A.; Nauges, C. Households' pro-environmental habits and investments in water and energy consumption: Determinants and relationships. J. Environ. Manag. 2014, 133, 174-183. [CrossRef]

80. Joachain, H.; Klopfert, F. Smarter than metering? Coupling smart meters and complementary currencies to reinforce the motivation of households for energy savings. Ecol. Econ. 2014, 105, 89-96.

81. Weber, S.; Puddu, S.; Pacheco, D. Move it! How an electric contest motivates households to shift their load profile. Energy Econ. 2017, 68, 255-270.

82. Havas, L.; Ballweg, J.; Penna, C.; Race, D. Power to change: Analysis of household participation in a renewable energy and energy efficiency programme in Central Australia. Energy Policy 2015, 87, 325-333. [CrossRef]

83. Kim, H.B.; Iwamatsu, T.; Nishio, K.I.; Komatsu, H.; Mukai, T.; Odate, Y.; Sasaki, M. Field experiment of smartphone-based energy efficiency services for households: Impact of advice through push notifications. Energy Build. 2020, 223, 110151. [CrossRef]

84. Webb, D.; Soutar, G.N.; Mazzarol, T.; Saldaris, P. Self-determination theory and consumer behavioural change: Evidence fromahousehold energy-saving behaviour study. J. Environ. Psychol. 2013, 35, 59-66. [CrossRef]

85. Pasini, D.; Reda, F.; Häkkinen, T. User engaging practices for energy saving in buildings: Critical review and new enhanced procedure. Energy Build. 2017, 148, 74-88. [CrossRef]

86. Bastida, L.; Cohen, J.J.; Kollmann, A.; Moya, A.; Reichl, J. Exploring the role of ICT on household behavioural energy efficiency to mitigate global warming. Renew. Sustain. Energy Rev. 2019, 103, 455-462. [CrossRef]

87. Cramér, H. Mathematical Methods of Statistics; Princeton University Press: Princeton, NJ, USA, 1946. [CrossRef]

88. Brzezińska, J. Analiza Logarytmiczno-Liniowa: Teoria i Zastosowania Z Wykorzystaniem Programu R; Wydawnictwo C.H. Beck: Warszawa, Poland, 2015.

89. Greenacre, M. Correspondence Analysis in Practice, 3rd ed.; Chapman and Hall/CRC Press: London, UK, 2021. [CrossRef]

90. Rozmus, D. Analiza korespondencji. In Metody Statystycznej Analizy Wielowymiarowej W Badaniach Marketingowych; Gatnar, E., Walesiak, M., Eds.; Wydawnictwo AE we Wrocławiu: Wrocław, Poland, 2004; pp. 283-315.

91. Stanimir, A. Analiza Korespondencji Jako Narzędzie Badania Zjawisk Ekonomicznych (Correspondence Analysis as a Tool for the Study Economic Factors); Wydawnictwo AE we Wrocławiu: Wrocław, Poland, 2005.

92. Kim, J.O.; Mueller, C.W. Factor Analysis: Statistical Methods and Practical Issues; Sage: Beverly Hills, CA, USA, 1978; ISBN 978-0803911666.

93. Kim, J.O.; Mueller, C.W. Introduction to Factor Analysis: What It Is and How to Do It; Sage: Beverly Hills, CA, USA, 1978; ISBN 9978-0803911659. [CrossRef]

94. Sztemberg-Lewandowska, M.; Zacny, B. Analiza czynnikowa. In Metody Statystycznej Analizy Wielowymiarowej W Badaniach Marketingowych; Gatnar, E., Walesiak, M., Eds.; Wydawnictwo AE we Wrocławiu: Wrocław, Poland, $2004 ;$ pp. $186-245$.

95. Sztemberg-Lewandowska, M. Analiza czynnikowa. In Statystyczna Analiza Danych Z Wykorzystaniem Programu R.; Walesiak, M., Gatnar, E., Eds.; Wydawnictwo Naukowe PWN: Warszawa, Poland, 2009; pp. 318-353.

96. Cronbach, L. Coefficient alpha and the internal structure of tests. Psychometrika 1951, 16, 297-334. [CrossRef]

97. Kruskal, W. A nonparametric test for the several sample problem. Ann. Math. Stat. 1952, 23, 525-540. [CrossRef]

98. Kruskal, W.; Wallis, W. Use of ranks in one-criterion variance analysis. J. Am. Stat. Assoc. 1952, 47, 583-621. [CrossRef]

99. D'Oca, S.; Hong, T.; Langevin, J. The human dimensions of energy use in buildings: A review. Renew. Sustain. Energy Rev. 2018, 81, 731-742. [CrossRef]

100. Han, X.; Wei, C. Household energy consumption: State of the art, research gaps, and future prospects. Environ. Dev. Sustain. 2021, 23, 12479-12504. [CrossRef]

101. Whitmarsh, L.; O'Neill, S. Green identity, green living? The role of pro-environmental self-identity in determining consistency across diverse pro-environmental behaviours. J. Environ. Psychol. 2010, 30, 305-314.

102. Bird, S.; Legault, L. Feedback and Behavioral Intervention in Residential Energy and Resource Use: A Review. Curr. Sustain. Energy Rep. 2018, 5, 116-126. [CrossRef] 
103. Weber, E.U.; Johnson, E.J. Psychology and Behavioral Economics Lessons for the Design of a Green Growth Strategy. Policy Res. Work. Pap. Ser. 2012, 6240, 1-50.

104. Abrahamse, W.; Steg, L. Social influence approaches to encourage resource conservation: A meta-analysis. Glob. Environ. Chang. 2013, 23, 1773-1785. [CrossRef]

105. Taufik, D.; Bolderdijk, J.W.; Steg, L. Going green? The relative importance of feelings over calculation in driving environmental intent in the Netherlands and the United States. Energy Res. Soc. Sci. 2016, 22, 52-62.

106. Andor, M.A.; Fels, K.M. Behavioral Economics and Energy Conservation-A Systematic Review of Non-price Interventions and Their Causal Effects. Ecol. Econ. 2018, 148, 178-210. [CrossRef]

107. Farrow, K.; Grolleau, G.; Ibanez, L. Social Norms and Pro-environmental Behavior: A Review of the Evidence. Ecol. Econ. 2017, 140, 1-13. [CrossRef]

108. Frederiks, E.R.; Stenner, K.; Hobman, E.V. Household energy use: Applying behavioural economics to understand consumer decision-making and behaviour. Renew. Sustain. Energy Rev. 2015, 41, 1385-1394. [CrossRef]

109. Jain, R.K.; Gulbinas, R.; Taylor, J.E.; Culligan, P.J. Can social influence drive energy savings? Detecting the impact of social influence on the energy consumption behavior of networked users exposed to normative eco-feedback. Energy Build. 2013, $66,119-127$.

110. Nakamura, H. Effects of social participation and the emergence of voluntary social interactions on household power-saving practices in post-disaster Kanagawa, Japan. Energy Policy 2013, 54, 397-403. [CrossRef]

111. Schultz, P.W. Power of Social Norms. Psycolog. Sci. 2007, 18, 429-434. [CrossRef] [PubMed]

112. Nakamura, E. Electricity saving behavior of households by making efforts, replacing appliances, and renovations: Empirical analysis using a multivariate ordered probit model. Int. J. Consum. Stud. 2016, 40, 675-684. [CrossRef]

113. Sloot, D.; Jans, L.; Steg, L. Can community energy initiatives motivate sustainable energy behaviours? The role of initiative involvement and personal pro-environmental motivation. J. Environ. Psychol. 2018, 57, 99-106.

114. Asensio, O.I.; Delmas, M.A. Nonprice incentives and energy conservation. Proc. Natl. Acad. Sci. USA 2015, 112, E510-E515. [CrossRef]

115. Zangheri, P.; Serrenho, T.; Bertoldi, P. Energy savings from feedback systems: A meta-studies' review. Energies 2019, 12, 3788 [CrossRef]

116. McKerracher, C.; Torrit, J. Energy consumption feedback in perspective: Integrating Australian data to meta-analyses on in-home displays. Energy Effic. 2013, 6, 387-405. [CrossRef]

117. Darby, S. Smart metering: What potential for household engagement? Build. Res. Inf. 2010, 38, 442-457. [CrossRef]

118. Buchanan, K.; Russo, R.; Anderson, B. The question of energy reduction: The problem(s) with feedback. Energy Policy 2015, 77, 89-96. [CrossRef]

119. Hargreaves, T. The Visible Energy Trial: Insights from Qualitative Interviews; Tyndall Centre for Climate Change Research: Norwich, UK, 2010; pp. 1-52.

120. Fischer, C. Feedback on household electricity consumption: A tool for saving energy? Energy Effic. 2008, 1, 79-104. [CrossRef]

121. Giordano, V.; Meletiou, A.; Covrig, C.F.; Mengolini, A.M.; Ardelean, M.; Fulli, G.; Jiménez, M.S.; Filiou, C. Smart Grid Projects in Europe:Lessons Learned and Current Developments 2012 Update, EUR 25815; Publications Office of the European Union: Luxembourg, 2013. 